NBER WORKING PAPER SERIES

\title{
AFFIRMATIVE ACTION IN EDUCATION: EVIDENCE FROM ENGINEERING COLLEGE ADMISSIONS IN INDIA
}

\author{
Marianne Bertrand \\ Rema Hanna \\ Sendhil Mullainathan \\ Working Paper 13926 \\ http://www.nber.org/papers/w13926
}

\author{
NATIONAL BUREAU OF ECONOMIC RESEARCH \\ 1050 Massachusetts Avenue \\ Cambridge, MA 02138 \\ April 2008
}

This project was funded by the National Science Foundation. We are grateful to Hardy K. Dewan for his assistance in obtaining the data, and IMRB for conducting the fieldwork. We thank Jessica Pan for outstanding research assistance. We thank seminar participants at Bocconi, Pompeu Fabra, the "Labor Markets in Transition and Developing Economies: Emerging Policy and Analytical Issues" conference (University of Michigan), the BREAD/CEPR conference (LSE), Caste Western Reserve University, NYU and University of Houston/Rice for helpful comments. The views expressed herein are those of the author(s) and do not necessarily reflect the views of the National Bureau of Economic Research.

NBER working papers are circulated for discussion and comment purposes. They have not been peerreviewed or been subject to the review by the NBER Board of Directors that accompanies official NBER publications.

(C) 2008 by Marianne Bertrand, Rema Hanna, and Sendhil Mullainathan. All rights reserved. Short sections of text, not to exceed two paragraphs, may be quoted without explicit permission provided that full credit, including () notice, is given to the source. 
Affirmative Action in Education: Evidence From Engineering College Admissions in India Marianne Bertrand, Rema Hanna, and Sendhil Mullainathan

NBER Working Paper No. 13926

April 2008

JEL No. I21,I38,J7

\begin{abstract}
$\underline{\text { ABSTRACT }}$
Many countries mandate affirmative action in university admissions for traditionally disadvantaged groups. Little is known about either the efficacy or costs of these programs. This paper examines affirmative action in engineering colleges in India for "lower-caste" groups. We find that it successfully targets the financially disadvantaged: the marginal upper-caste applicant comes from a more advantaged background than the marginal lower-caste applicant who displaces him. Despite much lower entrance exam scores, the marginal lower-caste entrant does benefit: we find a strong, positive economic return to admission. These findings contradict common arguments against affirmative action: that it is only relevant for richer lower-caste members, or that those who are admitted are too unprepared to benefit from the education. However, these benefits come at a cost. Our point estimates suggest that the marginal upper-caste entrant enjoys nearly twice the earnings level gain as the marginal lower-caste entrant. This finding illustrates the program's redistributive nature: it benefits the poor, but costs resources in absolute terms. One reason for this lower level gain is that a smaller fraction of lower-caste admits end up employed in engineering or advanced technical jobs. Finally, we find no evidence that the marginal upper-caste applicant who is rejected due to the policy ends up with more negative attitudes towards lower castes or towards affirmative action programs. On the other hand, there is some weak evidence that the marginal lower-caste admits become stronger supporters of affirmative action programs.
\end{abstract}

Marianne Bertrand

Graduate School of Business

University of Chicago

5807 South Woodlawn Avenue

Chicago, IL 60637

and NBER

marianne.bertrand@gsb.uchicago.edu

Rema Hanna

Wagner Graduate School of Public Service

New York University

295 Lafayette Street, 2Fl

New York, NY 10012

rnh4@nyu.edu
Sendhil Mullainathan

Department of Economics

Littauer 208

Harvard University

Cambridge, MA 02138

and NBER

mullain@ fas.harvard.edu 


\section{Introduction}

Many countries around the world mandate affirmative action in higher education, where groups that have historically faced discrimination are given preferential admissions. In the context we study—state controlled colleges in India-more than 50 percent of admissions slots are reserved for the members of lower-caste groups. In this paper, we empirically examine the impact of affirmative action in education to understand its effectiveness in redistributing both opportunity and income to marginalized groups.

We are motivated by the vigorous debate surrounding affirmative action programs. ${ }^{2}$ The debate is focused on two main issues. The first issue centers on the question of who these programs actually target. Many claim that affirmative action only benefits a small sliver of the population: those of the traditionally disadvantaged group that actually come from economically advantageous backgrounds. ${ }^{3}$ Specifically, if the marginal admit of the “disadvantaged" group comes from a richer household than the marginal admit of the "advantaged” group, affirmative action programs may actually be regressive in nature. Put another way, such programs may take slots from less advantaged members of an advantaged group and give them to individuals who are more advantaged, but just happen to belong to a less advantaged group. The second issue is whether and how much these programs actually help those who gain admissions—-the so-called "mismatch" hypothesis. ${ }^{4}$ One side argues that because these programs place minorities in an academic environment for which they are unprepared, those who gain admissions due to affirmative action will do poorly in classes, be more likely to drop out, and flounder in the job market. In the worst-case scenario, they could actually be worse off, either through lost time spent in college or through a discouragement effect. However, others argue that such programs may result in net gains for the disadvantaged groups — that is, that the targeted groups may not only benefit from the education they receive, they may actually benefit more than the traditionally advantaged groups. Thus, affirmative action would be consistent with an efficient reallocation of educational slots.

\footnotetext{
${ }^{2}$ Holzer and Neumark (2000) provide an overview of the efficiency aspects of affirmative action. Fryer, Loury, and Yuret (2003) also provide a theoretical analysis, which discusses the efficiency costs.

${ }^{3}$ In the US context, Bowen and Bok (1998) have examined affirmative action in higher education using detailed microadmissions data similar to our own though without an explicit regression design such as ours to examine outcomes. Arcidiacono (2005) has used a structural model to estimate the impact of affirmative action policies in higher education.

${ }^{4}$ The mismatch hypothesis has been discussed by Thernstrom and Thernstrom (1997), Herrnstein and Murray (1994), and D’Souza (1981). Loury and Garman (1993), Kane (1998), Alon and Tienda (2005), and Rothstein and Yoon (2007) empirically examine the mismatch hypothesis in the US context.
} 
Despite the importance of this debate, data restrictions have hampered a thorough empirical investigation. Existing studies of affirmative action are limited to studies of the outcomes of those who were admitted and matriculated. The lack of follow up data on those who do not gain admissions makes it hard to test several of the above hypotheses, such as the costs to those who "lost out.” As Fryer and Loury (2005) discuss, there are strong beliefs that affirmative action programs greatly harm non-minority groups and this belief dampens support for such programs. However, these beliefs are hard to evaluate, since there is very little real evidence to date on the magnitude (if any) of the harm. The lack of data on those who did not matriculate is particularly problematic. An individual may choose not to matriculate because he or she had better outside options, biasing the estimated impacts of affirmative action. For example, Rothstein and Yoon (2007), arguably the most informative paper on affirmative action in higher education to date, compares the outcomes of matriculants at higher quality US law schools versus lower quality law schools to assess the impacts of affirmative action policies. However, suppose that matriculation rates are lower for those who did not obtain admissions to higher quality law schools because only those who did not have better outside options attend the low quality schools. In this case, the analysis would overestimate the impacts of affirmative action. In contrast, this study assembles the most comprehensive dataset available on affirmative action in higher education (to our knowledge) by collecting detailed follow-up data on a pool of initial applicants, whether they were admitted and whether they matriculated.

We do so in the Indian context. In traditional Hindu society, individuals are born into a caste group that determines one's rights and responsibilities related to occupation, social standing, and permissible forms of social interactions with members of other caste groups. Since caste is hereditary and also tends to be occupation-specific, occupation was traditionally determined by birth (Osborne 2001). Recent work by Munshi and Rosenzweig (2005), for example, shows how caste-based labor markets have trapped individuals in narrow occupational categories for generations, and persist even today. In an attempt to reduce these caste-based inequalities, state universities in India reserve seats for individuals from each of the traditionally disadvantaged groups-the Scheduled Tribes (ST), the Scheduled Caste (SC), and the Other Backward Castes (OBC).

The system of admissions and reserved seats is quite straightforward. To apply to a university, each applicant sits for a standardized exam. Admission is a deterministic function of one's exam score and caste group. Within each caste group, only those who have scored above a given threshold for their caste group are admitted. 
Due to the structure of this process, we can isolate the marginal admits across castes to examine the impact of attending a college for each caste group. Specifically, we compare various outcomes for applicants above and below the admission threshold in each caste group. This allows us to investigate whether the "lower" caste groups, who are favored in admissions by the affirmative action policy, are actually helped by it. Moreover, we can describe which candidate (e.g. richer or poorer background) is being substituted for through the affirmative action policy. $^{5}$

We focus on individuals applying for entrance to engineering colleges in 1996 in one Indian state. We chose to study engineering colleges because they are among the most prestigious types of colleges in India. To implement our research design, we collected two data sets. First, we collected a census of all individuals who took the admissions exam in 1996. The minimum score for admission is roughly 480 out of 900 for upper-caste individuals, 419 for the OBC category, and 182 for the SC category. ${ }^{6}$ These score disparities at entrance confirm the plausibility of the hypothesis that lower-caste students will simply not be able to perform in college and, hence, will not benefit from admission because of the mismatch between their basic skill level and the skill requirements of an engineering education. To better understand outcomes across caste groups, we interviewed about 700 households from this census of applicants between 2004 and 2006 (approximately 8-10 years after the entrance exam). We surveyed both the applicant and their parents to gauge life outcomes including income and occupation, job satisfaction, social networks, and caste identity.

Our first finding is that, contrary to the arguments of some critics, caste-based targeting does result in the targeting of individuals who are more economically disadvantaged. For example, under a reasonable set of assumptions, the parental income among upper-caste students displaced by the affirmative action policy is Rs 14,088, compared to Rs 8,340 among the displacing lower-caste students. Similarly, 41 percent of displaced students come from a household in which the head holds at least a master's degree, compared to only 14 percent of displacing students. Fifty-nine percent of displaced students attended an English private school, compared to only 35 percent of displacing students. The one piece of countervailing evidence is that displaced students are disproportionately female. Specifically, 73 percent of those "displaced” by the reservation policy are males,

\footnotetext{
${ }^{5}$ This design inherently means we will not be estimating the impact of removing the entire affirmative action policy. Instead, we estimate how marginal winners and losers fare in the current context. This estimation is useful given that participants in the broader policy debate make different assumptions about how winners and losers fare.

${ }^{6}$ Applicants from the ST category were dropped from the analysis. Due to the large number of available seats and few candidates from this group, a large fraction of applicants from this category obtained admissions.
} 
compared to 84 percent of the "displacers.” As a whole, however, our evidence suggests that targeting by social group also serves (at the margin) to target the socio-economically disadvantaged.

We next examine labor-market outcomes. We find that, despite much lower basic skills (as measured by the score on the entry exam), those who are admitted by affirmative action economically benefit from attending engineering college. Depending on the specifications, attending engineering school increases lower-caste members' monthly income by between Rs 3,700 and Rs 6,200. This corresponds to an increase of 40 to 70 percent. This is (statistically and economically) indistinguishable from the rate of return enjoyed by upper-caste groups. In other words, we find no support for the mismatch hypothesis.

However, our estimates suggest that these programs come at an absolute cost. Specifically, attending engineering college increases the monthly income of the (displaced) upper-caste members by about Rs 5000 more than it increases the monthly income of the (displacing) lower-caste members (significant at the 15 percent level). Furthermore, our results for broad caste groups mask some underlying heterogeneity in which subgroups benefit. Specifically, in the lower-caste group, it is those from higher socio-economic backgrounds that appear to derive positive returns. ${ }^{7}$ This suggests that while lower-caste members do benefit from the policy, it is the economically better-off among them who benefit the most.

While access to higher education may improve earning potential, it could also increase access to more satisfying careers. Thus, we studied whether affirmative action affected job quality and satisfaction. While attending engineering college qualitatively improves job quality (as measured by variables such as likelihood of using a computer or speaking English at work) and job satisfaction among the lower-caste group members, it does not yield the same job quality “returns” to lower-caste group members as to upper-caste group members.

Finally, we also examine the impact of affirmative action on individuals' attitudes towards other castes and towards affirmative action programs in general. How are upper-caste applicants' attitudes affected by being denied a seat in engineering college due to reservations? How are lower-caste applicants' attitudes affected by being offered a seat in engineering college due to reservations? We find no evidence that upper-caste group members who "lose out" due to the policy end up with more negative attitudes towards lower castes or towards affirmative

\footnotetext{
${ }^{7}$ Due to the nature of our research sample, this statement is for a population with roughly similar scores for both groups.
} 
action programs in general. However, we find some weak evidence that the lower-caste group members who directly benefit from the reservation policy end up being stronger supporters of the programs.

The rest of the paper proceeds as follows. Section I discusses the history of affirmative action policies in India. Section II describes the data and methodologies. Our findings are presented in Section III. Section IV concludes with a discussion of our main findings and suggestions for future work.

\section{History of Affirmative Action Policies in India}

The roots of India's current affirmative action policies date back to the colonial-era reservation programs for government jobs, political representation, and scholarships established under British rule (Kumar, 1992). ${ }^{8}$ With independence from Britain in 1947, Jawaharal Nehru and the Congress Party chose to maintain the British system of reserving seats in the legislature (Osborne, 2001). Article 46 of India's Constitution contained a directive to provide special considerations to members of the Scheduled Castes (SC) and Scheduled Tribes (ST). ${ }^{9}$ While the Constitution originally banned any kind of discrimination in college admissions, it was amended in 1951 to allow the government discretion in whether to provide any special consideration for the advancement of the SC and ST. This paved the way for both the central government and the individual states to adopt reservations in college admissions (Weisskopt, 2003).

While the constitution prohibited discrimination against the "other backward categories” (OBC)—a group that was more advantaged than the SC and ST, but less advantaged than the upper-caste groups—it did not institute any affirmative action policies for them. In 1953, the central government formed a commission to study the situation of the OBC. The commission recommended that an additional 2,399 "backward" castes—roughly 40 percent of the population—should also be eligible for reservations (de Zwart, 2000b). This recommendation was not acted upon, however. Instead, the central government left the power to grant concessions to other backward caste groups to individual states. By the mid-1970s, states such as Tamil Nadu and Karnataka had instituted high

\footnotetext{
${ }^{8}$ The first recorded affirmative action policies in India were quota systems for administrative positions in the more progressive state governments, such as Mysore in South India, and Baroda and Kolhapur in Western India (Das, 2000). Political reservations soon followed: the first caste-based lists of reserved, parliamentary seats were published under British rule in 1936 (Osborne, 2001).

9 "The state shall promote with special care the education and economic interests of the weaker sections of people, and, in particular, of the scheduled castes and scheduled tribes, and protect them from social injustice and all forms of exploitation. Who is a member of the scheduled caste and scheduled tribes has been defined under article 366 of the Constitution.”
} 
quotas for the OBC (Baley, 1999). However, there were no reservations for the OBC in centrally-controlled institutes, such as the prestigious IITs and IIMs.

In 1978, the central government once again formed an exploratory commission—-known as the Mandal Commission — to explore again the situation of the OBC. It identified 3,747 castes, or 52 percent of the population, as backward (de Zwart, 2000b; Wolpert, 2006). It recommended reservations for all public-sector jobs and all private-sector endeavors that receive financial assistance from the government. It also recommended that reserved seats be held in university admissions for the OBC (Kumar, 1992; Weisskopt, 2003). The Commission would have preferred to recommend that the OBC groups receive a 52 percent quota, in addition to the 22.5 percent already set aside for SC and ST. ${ }^{10}$ However, the Supreme Court had already ruled that central-government reservations could not exceed 50 percent. As such, the Commission recommended a 27 percent reservation for the OBC (Wolpert, 2006). The report was shelved until 1990, when the central government reported that it would enforce only some of the recommendations of the Commission for public-sector jobs. This announcement led to widespread rioting and protest (Osborne, 2001). In 1992, the Supreme Court upheld the Mandal reservations of 27 percent for publicsector jobs for the OBC. It also ruled that the central government and all state governments must exclude the “creamy layer," i.e. richer members, of the OBC from the reservations in public sector jobs (Osborne 2001, Wolpert, 2006).

The original reservations specified in India’s Constitution were set to expire in 1960. They have since been extended several times over, and are now set to expire in 2010. In all colleges controlled by the central government, 7.5 percent of seats have been reserved for the ST and 15 percent of seats have been reserved for the SC, for a total of 22.5 percent of reserved seats. There are no reservations for the OBC in these centrally-controlled colleges. In colleges controlled by state governments, the percentage of seats reserved for ST/SC depend on the approximate proportions of these groups in each state. After the Mandal Commission, many states also implemented the 27 percent reservations for OBCs to varying degrees in state-controlled colleges.

Starting in 2005, reservations in education were once again at the forefront of Indian politics. In August 2005, the Supreme Court ruled that the State could not impose quotas in privately-funded colleges. The ruling led

\footnotetext{
${ }^{10}$ Limited data on the composition of caste existed, much less on the composition of caste by occupation, as the 1931 Census was the last census to have collected caste information. Thus, the population figures that are the basis of the reservations policy are much disputed, even today (Pande, 2003).
} 
to the passage of the $93^{\text {rd }}$ Constitution Amendment Act, which gave the State the power to institute affirmative action policies in all "educational institutions." ${ }^{11}$ In May 2006, the government announced a plan to extend the 27 percent reservation for the OBC to all central universities, resulting in massive protests. Parliament passed the bill in the winter session of 2006-2007. However, in March 2007, the Supreme Court gave a stay order on the bill, citing the lack of data on which groups are indeed economically and socially disadvantaged. Thus, as in many other countries, affirmative action continues to dominate the policy debate in India.

\section{Data and Methodology}

This section details the admission process for an engineering degree in the state where our research occurs. It also discusses the sample construction and survey design. We conclude with a discussion of attrition.

\section{Admission Process for an Engineering Degree}

During the start of his or her final year of high school, an individual must sit for a general college admissions examination (called the "10+2 examination”). The score on this exam and caste category fully determine admissions to most colleges. To gain admission into very prestigious programs or universities—such as medical and engineering colleges-in a particular state, each individual must first pass the $10+2$ exam. Individuals who have passed this exam can then take a second-round statewide entrance exam.

In this paper, we use data from the second-round entrance exam to engineering colleges in one Indian state. The exam consisted of three sections-math, physics and chemistry-each with 100 multiple choice questions worth 3 points each, for a total of 900 points. After taking the exam, individuals were ranked based on their total score for each caste category (General, OBC, SC, and ST). ${ }^{12}$ Starting from the highest ranking in each caste category, an individual was invited for a counseling session where he/she was informed about possibilities for admissions to the different engineering colleges. The individual then chose whether he/she would like to attend,

\footnotetext{
11 "Educational institutions" has been left undefined. Thus, many claim that this amendment now allows the government, if it chooses, to implement reservations in all levels of schooling, and not just university education.

${ }^{12}$ For individuals with the same score, individuals are ranked first by math score, then by chemistry score, and finally by physics score. In the circumstance that individuals have the same three scores, the birthday determines the time-the older individual obtains the higher rank. As such, each individual has a unique ranking.
} 
and if so, which college and type of engineering course he/she wanted to pursue. ${ }^{13}$ The process continued down the rankings until all seats in the colleges were full.

Since states can increase the reserved seats for each caste group, the actual percentage of reserved seats varies from state to state. In the state-year we study, a total of 2,643 seats were available, with 2,054 seats open to the reservations policy; the remainder were payment seats not covered by the policy. ${ }^{14}$ The quotas were determined by the distribution of castes in the state: there was a 16 percent reservation for the Scheduled Castes, a 21 percent reservation for the Scheduled Tribes, and a 14 percent reservation for the Other Backward Castes, for a total of 51 percent of seats reserved. Across each category, there were additional reservations for those who entered from a technical stream, were the child or grandchild of a "Freedom Fighter," or were military personnel (saniks).

As we indicated above, we obtained data from the 1996 entrance exam. For all individuals, the data included: individual's name, father's name, address in 1996, scores on each portion of the exam, rank, birth date, caste group, and an indicator for whether the individual qualified for any other reserved category. We also obtained a list of all applicants who actually attended engineering colleges in the state in 1996.

\section{Sample Determination}

When determining the research sample, we dropped two types of individuals. First, we excluded individuals who qualified for the special reserved categories (handicap, freedom fighter, etc.). Second, we excluded the ST category from the analysis as most of the ST applicants gained admission to the engineering colleges. For example, if we look at the bottom third of the test-score distribution for ST, 17 percent actually enrolled, which implies that many more were actually admitted; in comparison, there is a 0 percent enrollment rate in the bottom third of the test-score distributions for all the other caste groups. ${ }^{15}$

\footnotetext{
${ }^{13}$ Individuals with a higher ranking, therefore, get a choice about which institute to attend and which subject within engineering (major) to study. Since the reservation percentages cut across each institution and each branch, it is impossible to place all members from the reserved categories in only the worst colleges or branch.

${ }^{14}$ In many states, there is an oversupply of colleges. Therefore, the reservations are not always binding —individuals are not closed out of engineering colleges due to the quota systems. This was not the case in the state discussed in this paper in 1996. Thirty thousand nine hundred fifty-nine applicants sat for the exam to gain admission for 2643 seats across 14 engineering colleges. Due to the high demand for engineering degrees, this state saw a boom in engineering colleges, particularly unaided, private colleges. By 1998, the number of available seats rose to 4997.

${ }^{15}$ Unlike the other groups where about 5 to 8 percent of total applicants actually attended engineering universities, 28 percent of ST applicants went to an engineering college.
} 
Figure 1 presents test score distributions by caste category. As we already indicated above, lower-caste applicants, and especially SC applicants, scored lower on average on the entrance exam. The upper-caste group (general category) and OBC group also had a larger range of test scores than the SC group.

We planned to survey applicants who were both above and below the admission cutoff in each caste category. However, in this particular context, the "true" cutoff scores for admission are unknown. ${ }^{16}$ Thus, using the data on enrollments, we chose cutoffs of 182 for the SC, 419 for the OBC, and 490 for the upper-caste groups. These cutoff choices were validated using the method described in Chay, McEwan and Urquiola (2005), in which the selected cutoff maximizes the goodness of fit from a model of attending engineering college as a function of an indicator equal to one if one's score is below a particular threshold. Figure 2 graphs, for each caste category, the percentage of individuals who actually enrolled as a function of their test score. ${ }^{17}$ The vertical line on each graph indicates the aforementioned cutoff score for that caste category.

We selected a sample of applicants above and below their caste category cutoff. For the first round of surveys, we restricted ourselves to individuals who lived in one of the four more populous cities in terms of number of applicants. Conditioning on an address in one of these four cities, we then chose for the SC sample the 190 applicants right above the cutoff and 190 applicants right below the cutoff. This sample represented a higher percentage of total number of SC applicants than the 190 applicants right above and right below the cutoff for the other groups. We therefore calculated what percentage of the full list of SC applications our sample comprised, and determined ranges of test scores that corresponded to the same percentage for the other two caste groups. The OBC and upper-caste samples were then constructed by randomly choosing individuals above and below the cutoff within these test score ranges. Thus, we made a choice to not obtain more individuals closer to the cutoff for the upper-caste and other backward castes in order to obtain more comparable samples across caste categories. ${ }^{18}$ In total, we searched for 1,292 households across the three caste categories in the first wave of surveying that took place between October 2004 and May 2005. Between May and July 2006, a second wave of surveys was

\footnotetext{
${ }^{16}$ Note that because individuals who are higher ranked can choose which school (and major) they will attend, there could, in theory, be more than one discontinuity (e.g. there could be a discontinuity in admissions for each school and major). Unfortunately, we do not have a large enough sample size to evaluate the impact of admissions to each individual engineering school.

${ }^{17}$ To create Figure 2, the test score distribution for each caste group was broken into 50 bins of equal size, and the percentage of individuals who enrolled in each bin was graphed.

${ }^{18}$ We had briefly considered a second potential cutoff for the upper-caste group (590). Since we had two potential cutoffs for the upper-caste group, we chose a sample large enough to analyze the data for both cutoffs. The cutoff we ultimately selected for upper caste is the one that better predicted entry into engineering school in the first-stage regression.
} 
conducted in the next four more populous cities in terms of number of applicants. The research samples were constructed using the same methodology as for the four more populous cities. In this second wave of surveying, we searched for an additional 692 households. Therefore, in total, we searched for 1,984 households.

\section{Survey Design and Outcomes}

The survey consisted of two parts. The first part was directed at the parents of the applicant, while the second part was directed at the applicants themselves. Many questions, particularly parental background and child employment outcomes, were similar on both the parent and applicant surveys, so that if the applicant could not be interviewed, we could still collect their basic outcomes data from surveying their parents. When both the parent and the applicant could be located, we continued to ask each of them both sets of questions to be able to assess the accuracy of the parent's responses on applicant's educational and employment history.

In the survey, we collected data to inform the policy debate regarding affirmative action. First, we collected data on the background of parents to allow us to determine the social standing of those aided by the reservations. Second, we documented the educational and employment histories of the applicants to determine the economic consequences of attending an engineering college. Finally, we gathered information to understand whether educational opportunities also affected non-economic outcomes, such as the identity of one's friends or one’s perceptions and preferences.

Considerable effort was spent to locate as many households as possible. The enumerators first visited the parents' recorded address as of 1996 to determine if the parents still lived there. If the parents had moved, the enumerators went door to door and asked the neighbors for contact information. ${ }^{19}$ The survey was primarily conducted in person, but if the applicant or parents had moved out of the city, the survey was conducted by phone. Overall, 663 parents and 407 applicants were both found and agreed to participate in the survey, for a total of 721 households. ${ }^{20}$ The individuals in the upper caste category who were located and agreed to participate span the $56^{\text {th }}$ to $100^{\text {th }}$ percentile of the full test score distribution for their caste group. These figures are $56^{\text {th }}$ to $99^{\text {th }}$ percentile and $44^{\text {th }}$ to $88^{\text {th }}$ percentile for the OBC and SC, respectively.

${ }^{19}$ The survey team also looked up the contact information of individuals in the phone book, but this only captured moves within the city.

${ }^{20}$ An additional 172 families were located, but refused to be part of the survey. In most cases, when the individual could not be located, the family had moved and the neighbors did not have contact address. In a few cases, the address did not exist, the family never lived at the address, or the individual in question passed away. 
Appendix Table 1 compares located households with households that could not be located, by cutoff status and caste category. First, as Panel A shows, our ability to locate a given household was about the same regardless of whether or not that household was above or below the score cutoff; this is true for all three caste groups. In the remaining panels of Appendix Table 1, we compare basic characteristics (as available in the entrance exam data) between located and non-located households. Column 1 presents the difference (between located and non-located households) in the characteristic of interest for those above the threshold, while column 2 presents the same difference for those below the threshold. Column 3 presents the differences between Columns 1 and 2, with standard errors reported in parentheses below. While there are slight differences in test score, gender, age, and likelihood of attending engineering college between located and non-located households, these differences are not systematically related to the score cutoffs. ${ }^{21}$

When only the parents were found, we used data from the parents' survey to supplement the applicant's outcome information, and vice versa. To confidently use this method, we would expect that parents and children would be able to accurately answer questions regarding one another. Appendix Table 2 confirms that they do, showing high correlations between answers given by the child and his/her parent for key questions, such as father's income, applicant’s employment status, and applicant’s income.

\section{Results}

\section{Who applies to engineering colleges? Who gains admission due to the reservation policy?}

Table 1A reports on the socio-economic background of our survey respondents. For variables on family background, data from the parent survey were used when available; when the parent survey data were missing, data from the applicant survey were used. For the variables containing personal information on the applicant, data primarily come from the applicant survey; for cases in which the applicant was not found, the variable takes on the value of the equivalent question in the parent survey. Column 1 reports means for the entire sample; columns 2, 3, and 4 report means for upper-caste, OBC and SC groups, respectively. The p-values for comparisons of means across groups are reported in the remaining columns of Table 1A. Panel A focuses on characteristics of the main

${ }^{21}$ There have been a series of studies on attrition in developing countries, and they have concluded that survey attrition due to death or migration (even as high as 50 percent) has little impact on coefficient estimates (Fitzgerald et al, 1998, Falaris 2003). 
income earner in each applicant's household (as of 1996), while Panel B provides some background information about the applicants themselves. One star indicates significance at the 10 percent level, two stars indicate significance at the 5 percent level, and three stars indicate significance at the 1 percent level.

As a benchmark, we also provide in Table 1B socio-economic information for households from the urban areas of the Indian state where our research occurs. This table was constructed from the $55^{\text {th }}$ round of the National Sample Survey of India (NSS) that was conducted in 1999-2000. Unfortunately, the NSS does not contain all background variables we collected in our survey. Thus, Table 1B lists the following variables from the NSS that are most equivalent to the data we collected: a dummy variable for whether the head of household's education was below a graduate degree, a dummy variable for whether the head of household worked regularly, monthly consumption expenditures (in Rs 1999), and a dummy for whether the head of household works as an engineer. The column structure of Table 1B is identical to that of Table 1A.

Not surprisingly, applicants to engineering colleges are positively selected compared to other individuals in the state. While 80 percent of household heads in the NSS did not complete a graduate degree (where a graduate degree is equivalent to a U.S. college degree), this fraction is only 36 percent among applicants’ households. Applicants to engineering colleges are also more likely to be part of a household in which the head is employed. ${ }^{22}$ Finally, there is strong inter-generational correlation in career choice: while only about 1 percent of the households in the NSS are headed by engineers, 13 percent of the applicants to engineering colleges originate from households in which the head was an engineer.

Table 1B shows that the average lower-caste household in the state we study is relatively less educated and financially worse off than the average upper-caste household. Eighty-nine percent of heads of OBC households and 94 percent of heads of SC households have not completed a graduate degree, compared to 70 percent among uppercaste households. Upper-caste households in the NSS also report higher levels of monthly consumption expenditures: they consume about 33 percent more than OBC households and 60 percent more than SC households. Finally, engineers are more common household heads among the upper-caste group (2 percent) than among the OBC and SC groups (1 percent and 0.2 percent, respectively).

\footnotetext{
${ }^{22}$ Note that the employment status question in the NSS is not completely equivalent to the employment status question in our survey.
} 
A comparison of the information in Tables $1 \mathrm{~A}$ and $1 \mathrm{~B}$ shows that the positive selection among applicants to engineering colleges occurs across all three caste groups. Importantly, though, the positive selection among OBC and SC applicants is not so severe that their background characteristics become similar to those of the upper-caste applicants. Instead, there remain large and statistically significant differences in socio-economic background between the lower- and upper-caste groups (Table 1A). For example, 30 percent of heads of upper-caste households have at least a master's degree, compared to 16 and 13 percent for OBC and SC households, respectively. There are also systematic differences in parental income across the three groups, with heads of lowercaste households earning 30 to 40 percent less than heads of upper-caste households. Furthermore, lower-caste applicants are less likely to have attended an English-language private school and more likely to have attended a government school. While OBC applicants are better off than SC applicants, on average, the "economic distance" between these two types of applicants is smaller than the distance between the average upper-caste and average lower-caste applicant; this is especially true with regard to parental education and income. Table $1 \mathrm{~A}$ also shows that lower-caste applicants are typically older and have more siblings. Finally, a larger fraction of lower-caste applicants are males.

The systematic differences we observe in the socio-economic background of applicants of different castes are relevant in light of the active debate over who benefits from affirmative action programs in India. The summary statistics in Table 1A suggest that, in this particular context at least, targeting applicants from lower castes also results in targeting applicants who are economically less advantaged.

To more formally analyze this issue, we compare the socio-economic characteristics of the applicants offered a seat in an engineering college in 1996 due to the reservation program to the characteristics of those that were refused a seat but would have been admitted in the absence of the program. To perform this exercise, we make several assumptions. First, we assume that the number of applicants in each caste category, as well as their exam score, would be unaffected by the removal of affirmative action. Second, we assume that the total number of available seats in engineering colleges would remain the same in the absence of affirmative action. Finally, we also need to make an assumption about what the enrollment rate would be among those who would be offered a seat in the absence of affirmative action. The exam data show that the average enrollment rate is about 50 percent for the upper-caste group. However, admissions are made on a rolling basis and the rate is closer to 60-70 percent for 
those who were informed earlier of their acceptance. Therefore, we consider two different scenarios: 50 and 70 percent enrollment rates.

With these assumptions, we can calculate the score on the entry exam that would have been the threshold for admission in the absence of the reservation policy—-that is, in an environment in which all applicants are ranked on the same list. This threshold score is, by construction, higher when we assume a 70 percent rate than when we assume a 50 percent rate. Using the respondents' score on the entry exam, we can then identify the individuals who would have been admitted in the absence of the reservation policy and those who would not have been admitted. We can also compare the socio-economic background of those who would have been admitted but were not (e.g. the "displaced”) and those who would not have been admitted but were (e.g. the “displacing”). We present this comparison in Table 2. We assume a 50 percent enrollment rate in Columns 1 through 3, and a 70 percent rate in Columns 4 through 6. Columns 1 and 4 report average background characteristics for displaced applicants, while Columns 2 and 5 report average background characteristics for displacing applicants. We report the p-values for tests of comparison of means in Columns 3 and 6. The background characteristics we consider are the same as in Table 1A.

Table 2 confirms that the reservation policy is associated with the admission of individuals of a lower socio-economic background. Under the assumption of a 70 percent enrollment rate, mean parental income among the displaced individuals is Rs 14,088 compared to Rs 8,340 among the displacing individuals; 41 percent of displaced individuals come from a household in which the head holds at least a master's degree, compared to only 14 percent of displacing individuals; also, 59 percent of displaced individuals attended an English-language private school, compared to only 35 percent of displacing individuals. Not surprisingly, the economic magnitude of the difference between displacing and displaced individuals is smaller under the assumption of a 50 percent rate than under the assumption of a 70 percent rate, as the former assumption implies a lower threshold for admission and, hence, draws fewer of the displaced students from the (economically better-off) general caste category. Even under the 50 percent assumption, there is no evidence that the caste reservation policy discriminates against the economically weak, as some opponents of this policy have argued.

However, we find that the policy appears to hurt female applicants. This pattern emerges regardless of the enrollment rate assumed, but is only statistically significant under the assumption of a 50 percent rate. Under the 
assumption of the 50 percent rate, 73 percent of those "displaced” by the reservation policy are males, compared to 84 percent of those "displacing." This finding is not surprising given that the share of female applicants is higher in the upper-caste group than in the OBC and SC groups. ${ }^{23}$ This suggests that the targeting of lower castes may negatively interact with the advancement of women on the engineering career track.

\section{Summary Statistics: Labor Market Outcomes and Attitudes by Caste Category}

In Table 3, we summarize our main outcome variables. For each variable, we report average outcomes across all survey respondents — that is, whether or not they were admitted and whether or not they went to an engineering college-for the full sample (Column 1), for the upper-caste group (Column 2), for the aggregated lower-caste group (OBC plus SC, Column 3), as well as for OBC and SC (Columns 4 and 5, respectively). In Column 6, we report the p-value of a comparison of means between the upper- and aggregated lower-caste groups.

At the time of survey, lower-caste applicants, and especially SC applicants, are on average economically worse off as compared to upper-caste applicants. Eighty-one percent of the upper-caste applicants are employed compared to only 69 percent of the lower-caste applicants. The employment rate for SC applicants is especially low (58 percent). While OBC applicants do not differ much from the upper caste in terms of their employment rate, their income is substantially lower (Rs 12,361 per month for OBC compared to Rs 17,706 for the upper-caste group). Unemployed individuals have "zero" income, and therefore it is unsurprising that the SC members, who have a relatively lower employment rate, also have a much lower income (Rs 5,630) than the other groups.

Lower-caste and upper-caste applicants also hold different types of jobs. Upper-caste applicants are more likely to work as engineers and to be employed in the private sector; they are also more likely to use a computer at work and to speak English on the job. These differences are especially salient for the SC group. For example, 65 percent of upper-caste applicants use a computer at their current job, compared to only 31 percent of SC applicants; 47 percent of upper-caste applicants work as engineers, compared to only 28 percent of SC applicants. Also (and possibly related), SC respondents are much less likely to view their job as "a success." ${ }^{24}$ There are no statistically

${ }^{23}$ Henriques and Wankhede (1985) find that individuals from lower-caste groups that complete secondary school disproportionately tend to be male. Thus, it follows that college applicants from these lower-caste groups would also disproportionately tend to be male.

${ }^{24}$ The measure "Strongly agrees-views job as successful" is an index where one point is assigned for each of the following statements with which the individual strong agrees: The chances of promotion at work are good, promotions are handled 
significant differences across the groups in the likelihood of having relied on social networks (friends and family) to find their current or last job, even though the averages point towards slightly less use of social networks among SC applicants (7 percent, compared to 11 percent among upper-caste applicants).

We also included a series of more subjective questions in the survey to gauge respondents' level of civic engagement, social identity and attitudes towards affirmative action programs. These questions were only asked to the children and not to their parents, as we thought it would be difficult for parents to provide answers about how their children "feel" on these subjective dimensions; sample sizes are therefore smaller for this last set of variables. "Participates in government" is an indicator variable for whether the individual has voted in the last election or donated money to a political party. According to this measure, there is a higher level of civic engagement in the lower-caste than in the upper-caste group. The variable "Index of caste identity" aggregates four questions on caste identity into a single index. Specifically, it is a categorical variable that ranges from 0 to 4 and is defined as the sum of the following binary variables: belongs to BJP (a Hindu Nationalist Political Party), attends religious activity at least once a month, donates to religious organizations, and belongs to a caste association. The mean of this index variable is quite low on average (1.10); the mean is higher for lower-caste applicants (1.16 versus 0.98), suggesting they might have a stronger sense of their caste and religious identity. Lower-caste applicants also report stronger support for reservation policies. This is true, perhaps not surprisingly, for reservations that favor lower castes but also for reservations that favor females. For example, 64 percent of SC applicants, but only 40 percent of upper-caste applicants, agree with reservations for females in engineering colleges.

\section{Labor Market Effects: OLS Estimates}

In Table 4, we report OLS estimates of the impact of attending an engineering college (went $\mathrm{i}_{\mathrm{i}}$ ) on labor market outcomes:

$$
\text { Outcome }_{i}=\beta_{0}+\beta_{1} \text { went }_{i}+\beta_{2} X_{i}+\varepsilon_{i}
$$

We present these estimates for the full sample of respondents (Panel A), but also separately for the upper-caste group (Panel B) and lower-caste groups (OBC+SC in Panel C, OBC only in Panel D and SC only in Panel E). The outcomes we focus on are whether the individual is employed at the time of survey (Columns 1 and 2), monthly 
income in Rs (Columns 3 and 4), the logarithm of monthly income (Columns 5 and 6), and a dummy variable that equals 1 if the individual earns less per month than the median income in the full sample of respondents and zero otherwise (Columns 7 and 8). For each outcome variable, we report the results of two regression models: one in which we only control for a vector of individual characteristics (odd columns) and one in which we control for individual characteristics, household characteristics, and city of origin (even columns). The individual-level controls are dummies for OBC and SC categories, a gender dummy, the logarithm of age, and dummies for the type of secondary school attended (e.g. English private school, Hindi private school, or government school). The household-level controls are household-head monthly income as of 1996 (in Rs), dummies for the educational attainment of the household head, a dummy for whether the household head is an engineer, a dummy for whether or not the household head uses a computer at work, and the number of other children in the household. We also control for whether the data come from the parent or child survey in all regressions.

In the full sample (Panel A), we find that individuals who started engineering school in 1996 are about 6 percentage points more likely to be employed at the time of our survey (Column 1) and earn between Rs 3,500 to Rs 4,000 more per month (Columns 3-4); they are also about 10 percentage points less likely to have earnings that are below the sample median (Columns 7-8). The addition of controls for household characteristics tends to reduce the magnitude of the estimated coefficients, but the changes are economically small and are not statistically significant.

In Panels B and C, we compare OLS estimates of the returns to attending engineering college between the upper- and aggregated lower-caste groups. Employment effects (Columns 1 and 2) are of similar magnitude for both groups (about 5 percent) but are noisily estimated. Income-level effects are statistically significant for both groups but are larger in magnitude for upper-caste applicants. Attending engineering college in the state in 1996 is associated with an additional Rs 5,400 per month for upper-caste applicants and Rs 3,200 for lower-caste applicants in the econometric specification in which we only control for individual-level characteristics. The difference is smaller (Rs 3,700 versus Rs 2,700) in the specification in which we also control for household-level characteristics. Since the lower-caste group has lower earnings on average (Table 3), attending engineering school is associated with a higher percentage increase in income for that group. Specifically, attending engineering school increases monthly income by 80 to 90 percent for lower-caste respondents (statistically significant) compared to 50 to 70 
percent for upper-caste respondents (not statistically significant); because standard errors are large, we cannot statistically reject the hypothesis that these effects are of the same magnitude. For both the lower- and upper-caste groups, attending engineering college is associated with about a 10 percentage-point decrease in the likelihood of earning less than the sample median.

Disaggregating the lower-caste applicants into OBC and SC (Panels D and E respectively), we find positive and significant income-level effects for both groups (Rs 3,900 for OBC and Rs 3,000 for SC) in the specification in which we only control for individual characteristics. The estimated effect for OBC becomes smaller when we add household-level controls; in contrast, the estimated effect for SC applicants is virtually unchanged with the addition of these controls. The estimated employment effects of attending engineering college are positive, but noisy. Attending engineering college is associated with 15 to 20 percent reduction in the likelihood of earning belowmedian earnings for OBC applicants; in contrast, it does not lift SC applicants (who earn much less on average) from the bottom half of the earnings distribution in our sample.

In summary, the OLS regressions reported in Table 4 suggest positive and significant returns to attending engineering college, even in the lower-caste groups. In particular, even among SC applicants, who are characterized by much weaker socio-economic background and much lower test scores at entry, we find a positive association between attending engineering school and current income level. This contradicts the extreme view that seats in engineering colleges are "wasted" on lower-caste candidates because they do not have the preparation to utilize the engineering degree.

From a welfare perspective, these OLS point estimates of income-level effects suggest that a seat in engineering college occupied by a lower-caste applicant yields lower economic returns than if that same seat was occupied by a general-caste applicant. Reserving seats to lower-caste applicants might reduce the returns on the investment made in engineering colleges. The OLS point estimates also suggest, however, that the reservation policy might succeed in minimizing inequalities between caste categories, as illustrated by the larger log (income) effects for the lower-caste groups. It is worth stressing, however, that the large standard errors prevent us from drawing unequivocal conclusions. Another obvious limitation of the OLS estimates is that they do not unambiguously warrant a causal interpretation. We turn to this issue in the next section. 


\section{Labor Market Effects: IV Estimates}

\section{Empirical Strategy}

While a natural starting point, the OLS results reported above are subject to important interpretational issues. Our sample includes students who scored above and below the admission threshold in their caste category on the 1996 entry exam. Part of the variation in who attended engineering college that we exploit in the OLS regressions is driven by variation in who scored above and below the admission threshold in their caste group, while another part of the variation is driven by one's decision of whether or not to attend, conditional on having been admitted. This second source of variation is clearly problematic when one tries to measure the causal effect of attending engineering college. First, suppose that only those applicants who saw the greatest return to going to engineering college did so. In this case, we would clearly overestimate the causal effects of attending engineering college. Second, the decision of whether or not to attend, conditional on having been admitted, may be driven by liquidity constraints at the household level, with cash-constrained individuals not being able to forego several years of earnings in order to invest in education. ${ }^{25}$ Third, the selection into attending, conditional on having been admitted, may also reflect variation in outside options. For example, suppose that a seat in medical school is preferred to a seat in engineering school; then only those who did not make it into medical school will attend engineering school. Hence, we have included among those who did not attend engineering school some individuals who went instead to medical school, leading us to underestimate the causal effect of attending engineering school. Furthermore, if there is systematic variation in the quality of these outside options across caste categories, this would invalidate any comparison of the OLS returns to attending engineering college across caste categories. For example, if upper-caste applicants systematically have superior outside options than lower-caste applicants, the OLS model might give us an underestimate of the difference in the returns between the upper- and lower-caste groups.

In this section, we propose alternative estimates of the returns to attending engineering college that only rely on the first source of variation listed above: variation in who scored above and below the admission thresholds on the entry exam. Specifically, we will use score-cutoff dummies (cutoff $\mathrm{i}_{\mathrm{i}}$ ) as instruments for attending engineering college (went $)_{\mathrm{i}}$ ):

\footnotetext{
${ }^{25}$ These first two sources of bias in the OLS estimates are possibly relatively less important in our research setting in that we focus on individuals who decided to apply to engineering college. For example, if applying is costly, one might expect only those without binding cash constraints to make that decision.
} 


$$
\text { went }_{i}=\beta_{0}+\beta_{1} \text { cutoff }_{i}+\beta_{2} X_{i}+\varepsilon_{i}
$$

Relying only on this source of variation allows us to rule out biases due to selection in the decision to attend, conditional on having been admitted.

One remaining concern, of course, is that there are systematic unobservable differences between those who scored above and below the admission thresholds that would induce differences in their current labor-market outcomes, even in the absence of an engineering education. We attempted to form a homogenous group of survey respondents, given our survey constraints. Our sample is first limited to the group of individuals that passed the first-round 10+2 examinations. We then limited our sample to those who scored in the upper half of the secondround entrance exams. Below, we formally test for whether our sample forms a homogenous group for a set of observable background characteristics. We then go one step further and restrict the sample of survey respondents to those whose score on the entry exam is even closer to the cutoff for their caste category. In practice, we construct for each caste category a "discontinuity sample" in which we drop those survey respondents who scored below the $25^{\text {th }}$ percentile or above the $75^{\text {th }}$ percentile of the score distribution of all those surveyed in their caste category. Thus, the test scores in the general-caste discontinuity sample range from the $85^{\text {th }}$ to the $97^{\text {th }}$ percentile of the distribution of test scores among general caste entry exam-takers in 1996; the equivalent ranges are $84^{\text {th }}$ to $96^{\text {th }}$ percentile and $77^{\text {th }}$ to $92^{\text {nd }}$ percentile for the OBC and SC samples, respectively.

As we just discussed, we start in Table 5 by testing whether, within each caste category, there are any systematic differences in pre-characteristics between those who score above and below the cutoff on the entry exam. If there are no systematic differences in observable characteristics, one may feel more confident that there are no systematic differences in unobservable characteristics around that cutoff. Each cell in Table 5 corresponds to a different regression. Each regression relates the dependent variable in that row on the cutoff dummy that is relevant for the group in that column. Reported in each cell is the estimated coefficient on the cutoff dummy, with standard errors in parentheses. When we pool both lower-caste groups together (Columns 3 and 4), we also include in each regression a dummy for OBC status. Odd columns focus on the full samples and even columns focus on the discontinuity samples.

There are very few cases in which we find statistically significant differences between those applicants who are above the cutoff and those who are below. This is true in both samples. Not surprisingly, in many cases the 
magnitude of the estimated coefficients on the cutoff dummies are smaller in the discontinuity samples than in the full samples, but there are several exceptions. To determine the joint significance of the cutoff variables on all of the outcomes, we estimated a SUR model; we list the chi-square statistic and p-value that tests for the joint significance of the cutoff variable in the SUR model in the final two rows of Table 5. This test, and the other evidence reported in Table 5, confirms that applicants above and below the cutoff do not appear statistically different in terms of their background characteristics, thus providing some support for our strategy of using the score cutoff dummies as instruments for having attended engineering college.

\section{First- and Second-Stage Results}

We report the first-stage regressions in Table 6. Panel A focuses on the upper-caste group, while Panel B focuses on the aggregated lower-caste sample. Panel C focuses on the OBC group and Panel D on the SC group. The dependent variable in all regressions is "went," a dummy variable that equals 1 if the individual enrolled in engineering college in 1996 in the state under study and 0 otherwise. We consider six different models. Models 1 through 4 use the full samples of survey respondents within a given caste category. Model 1 simply consists of regressing "went” on a dummy for the group-specific cutoff (as well as a dummy for the OBC category in Panel B). In Model 2, we also include the individual-level controls introduced in Table 4 and an indicator variable for whether the outcome variables come from the parent or applicant survey, while Model 3 includes the control variables from Model 2 plus the vector of household-level characteristics from Table 4. Model 4 adds fixed effects for each applicant's origin city. Models 5 and 6 use the discontinuity samples, with Model 5 simply regressing "went" on a dummy for the group-specific cutoff and Model 6 replicating Model 4 (e.g. including the full list of controls).

All of the first-stage regressions reported in Table 6 statistically confirm the strong association already observed in Figures 2A, 2B and 2C between the likelihood of attending engineering college in 1996 and scoring above the cutoff on the entry exam. Not surprisingly given our findings in Table 5, the addition of individual- and household-level characteristics to the econometric model barely changes the estimated coefficients on the cutoff variables in either the full sample or the discontinuity sample. 
The smaller estimates on the cutoff dummy for upper-caste applicants compared to lower-caste applicants (Panel A versus Panel B) indicate that a smaller fraction of upper-caste admits end up attending engineering college. This could possibly reflect the fact that the general-caste admits face a larger set of educational choices. Interestingly, though, among the lower-caste applicants, it is the OBC admits that end up attending engineering college at a much higher rate; the estimated coefficient on the cutoff dummy in the SC group is in fact comparable in magnitude to the estimated coefficient on the cutoff dummy for the non-minorities. ${ }^{26}$

We report the two-stage least squares estimates of the impact of attending engineering college on labormarket outcomes in Table 7. The outcomes we consider are the same as in the OLS regressions (Table 4): likelihood of employment, monthly income level, log (income), and a dummy for monthly income below the sample median. We report the results for six different empirical models, which correspond to the first-stage specifications we presented in Table 6.

Models 1 through 4 include all survey respondents in the regression analysis. One can see that the point estimates on the returns to attending engineering college are similar across four of these specifications. The IV estimates tend to be larger than the OLS estimates presented in Table 4. For example, attending engineering college is associated with about a 15 percent increase in the likelihood of employment for upper-caste applicants in the IV regressions, compared to only a 5 percent increase in the OLS regression. The same holds for lower-caste applicants, although for this group the IV estimates are only about twice the size of the OLS estimates (about 10 percent versus 5 percent). The pattern in the gap between the IV and OLS estimates also extends to monthly income level. Attending engineering college increases the monthly income of upper-caste individuals by between Rs 9,500 and Rs 13,000 (statistically significant in all four specifications); in contrast, attending engineering college increases the monthly income of lower-caste applicants by between Rs 5,500 and Rs 6,200 (statistically significant in all four specifications). Hence, the point estimates in these IV specifications paint a less favorable picture of the welfare implications of the reservation policy: attending engineering college increases the monthly income of an upper-caste candidate by Rs 3,000 to Rs 7,000 more than it increases the monthly income of a lower-

\footnotetext{
${ }^{26}$ One possible explanation for the higher yield rate among the OBC admits is that they have fewer chances of attending an engineering college outside the state, as the centrally-controlled engineering universities (like the prestigious IITs) only have reservations for the SC category (and ST category), and not the OBC category.
} 
caste $_{\text {candidate. }}{ }^{27}$ This difference in income is marginally significant: controlling for all background characteristics (Model 4 from Table 7), the difference in incomes between the upper- and lower- caste groups is about Rs 5000, significant at the 12 percent level.

When we split the lower-caste group into OBC and SC candidates (Panels C and D respectively), one can see that the between-caste difference in the returns to an engineering education is especially large when we compare general-caste applicants to SC applicants. In Models 1 through 4, attending engineering college increases the monthly income of SC applicants by only about Rs 3,500 to Rs 4,500 (statistically significant in all four specifications), compared to about Rs 6,300 to Rs 8,200 for OBC applicants (statistically significant in all four specifications). In general, the estimated effects on the other outcomes for SC applicants, while all of the expected sign, are noisy. Interestingly, we cannot reject the hypothesis that the returns between the upper-caste group and OBC are the same. However, controlling for all background characteristics (Model 4 from Table 7), we find that the upper caste experience a Rs 6,900 higher return to admittance relative to the SC group (significant at the 15 percent level). Remember that the OBC, while of a lower socio-economic background, are much more similar in background characteristics to the upper-caste group than the SC. Thus, this begins to suggest that most of the costs of affirmative action come from admitting those from a much lower socio-economic background. We will more formally test this hypothesis in Table 9.

In Columns 5 and 6, we present results from the analysis of the discontinuity samples, in which we drop the top 25 percent and bottom 25 percent of scores in each caste group. Unfortunately, the estimated effects are noisy. Only one estimated coefficient is statistically significant at standard levels; namely, in Model 5, we find that attending engineering school reduces by 30 percent the likelihood that an OBC individual will earn below-median income. This lack of power is, in part, a reflection of the small sample sizes in the discontinuity regressions. In terms of magnitude, though, the point estimates in Columns 5 and 6 are roughly consistent with those in Columns 1 through 4: there are positive returns to attending engineering college even among the lower-caste groups that scored very poorly on the entry exam; attending engineering college increases the monthly income of a upper-caste candidate by about Rs 8,000 more than a lower-caste candidate (Panel A versus Panel B). However, in contrast with

\footnotetext{
${ }^{27}$ Of course, the economic costs could be even higher if the program moves individuals from attending government schools to attending private colleges.
} 
Columns 1 through 4, we see less evidence in these columns of superior returns for OBC applicants relative to SC applicants.

In Table 8, we replicate the IV models estimated in Columns 1 through 4 of Table 7, but also include a quadratic control for the individual's test score on the entry exam (score and score ${ }^{2}$ ) in each model. ${ }^{28}$ We compare upper- to lower-caste applicants (Panels A and B, respectively). We report in the first row of each panel the estimated coefficient on the threshold dummy in the relevant first-stage regression. In general, the estimated coefficients for the lower-caste groups (Panel B) are similar in economic magnitude to the results in Table 7, suggesting positive returns to attending engineering college for lower-caste applicants. However, the standard errors increase in size. The most statistically significant and stable patterns across models are a positive impact of attending college on the logarithm of monthly income for lower-caste applicants, and a negative impact on the likelihood of their earning below-median income. The estimated effects for the upper-caste applicants appear much less stable (Panel A) and we lose power in the first stage. Comparing Panels A and B, the estimated effects in Columns 1 and 3 are still consistent with the idea that upper-caste applicants obtain higher gains in income level from attending engineering school, with differences ranging between Rs 6,000 and Rs 13,000. However, as in the discontinuity sample analysis in Table 7, this comparison relies on estimates that are very imprecise. Maybe pointing towards the limits of our data and research design, the point estimate of attending an engineering college on income falls to about Rs 5000 for the upper caste group in Column 4 when we further include fixed effects for origin city of the applicant, with very large standard errors.

In summary, the findings in Tables 7 and 8 suggest that, contrary to the arguments of some critics of affirmative action, lower-caste applicants derive positive returns from affirmative action. However, the bulk (but not all) of the evidence in these tables also suggests some aggregate costs to these programs: allowing an uppercaste applicant to occupy a seat that has been reserved for a lower-caste applicant would boost aggregate income.

In Table 9, we investigate whether there is heterogeneity in the income effects we estimate based on the socio-economic background of the applicants. To proceed, we first summarize a given individual's socio-economic background characteristics into a single index. We do this by regressing a given individual's test score on the vector

\footnotetext{
${ }^{28}$ It is unclear whether the quadratic is the right fit, given the shape of the data distributions shown in Figure 2. Moreover, in the first stage regressions, the score and score ${ }^{2}$ variables are not significant predictors of attending the engineering colleges. Nonetheless, we present this analysis for completeness.
} 
of individual and household background variables introduced above; from this estimation, we compute a predicted test score variable and assign each individual a dummy variable that equals 1 if the individual's predicted test score is below the median within her caste category and 0 otherwise. We then replicate in Columns 1 and 2 of Table 9 the IV models estimated in Columns 1 and 4 of Table 7 but add to the models an interaction term between going to engineering college and the "below median predicted score" dummy. ${ }^{29}$ Column 3 of Table 9 replicates Column 1 but replaces the predicted test score dummy with the continuous predicted test score variable.

The most striking finding in Table 9 is for lower-caste applicants (Panel B). For this group, we find very different returns to attending engineering college by socio-economic background. Applicants who come from a better background benefit more from attending engineering college than those from lower socio-economic backgrounds. This pattern holds in all three columns of Table 9. In fact, our estimates indicate very small returns to attending engineering school among those lower-caste applicants who come from poorer backgrounds. This suggests some strong complementarities between education and socio-economic background for lower-caste candidates. In contrast, we see no such complementarities for upper-caste applicants. In fact, the effects we estimate point toward higher returns to attending engineering college among the upper-caste applicants coming from poorer socio-economic backgrounds. ${ }^{30}$

Hence, the findings in Table 9 paint a somewhat less optimistic picture of the reservation policy when it comes to benefiting lower-income groups (and not just lower-caste groups). Specifically, while we showed earlier (in Table 2) that the targeting of lower-caste groups does lead to the admission of students of a lower socioeconomic background, Table 9 suggests that the reservation policy may provide greater benefits to those who are already economically better-off within the lower-caste groups. We can hypothesize on possible channels through which socio-economic status (SES) may continue to affect outcomes, post-admission. First, higher SES lower-caste members may find it easier to make it through college. For example, they may not need to work during college or they may be better able to draw upon friends and family in the learning process. Second, higher SES lower-caste

\footnotetext{
${ }^{29}$ We of course also include the "below median predicted score" dummy as a direct control. The estimation of the 2SLS models now relies on two instruments: the score threshold dummy and the score threshold dummy interacted with the "below median predicted score" dummy.

${ }^{30}$ These results are not surprising in light of the fact that we see higher level returns for the OBC group than the SC group. Furthermore, if we look within the OBC and SC groups, we find that most of the gains within group are also concentrated among those who are from a higher socioeconomic background.
} 
members may find the post-graduation job market easier to navigate. For example, their social networks may help them take better advantage of their degree.

\section{Other Outcome Variables}

In the final two tables, we extend the analysis to other outcome variables besides employment and income. Table 10 reports on various job characteristics and Table 11 reports on variables related to one's social network as well as on a set of beliefs and attitudes. For brevity, we only present IV estimates for these outcomes. Tables 10 and 11 follow the same structure as Table 7. For each dependent variable of interest (as listed in the first column), we present the results of six different models corresponding to the six first-stage specifications from Table 6. Each cell corresponds to a separate regression and reported in the cell is the estimated coefficient on "went to engineering college” (with standard errors in parentheses). In both tables, Panel A focuses on the upper-caste sample and Panel B on the aggregated lower-caste sample.

Table 10 suggests that attending engineering college has a strictly positive, but smaller, impact on one’s likelihood of working as an engineer for lower-caste compared to upper-caste individuals (Row 1). More generally, the likelihood of working in an advanced technical field, which we proxy for by one's using a computer at work, is only at most 11 percentage points higher for those in the lower-caste group that attended engineering school (not statistically significant), compared to about 30 percentage points higher for those in the upper-caste group (statistically significant in all specifications). Other job characteristics also suggest a differential impact on job quality between lower-caste and upper-caste applicants. While attending engineering school increases the likelihood of one's using English at work for both groups, this effect is larger in magnitude in the upper-caste group. ${ }^{31}$ More generally, engineering school increases one's level of job satisfaction (as measured by the index variable "strongly agrees - views job as successful”) more for general-caste compared to lower-caste members. ${ }^{32}$ We interpret these results as consistent with our earlier findings that lower-caste candidates do benefit from attending engineering college, but that the benefits they receive from this education do not match the benefits that “displaced” upper-caste applicants might have gotten, absent the policy.

${ }^{31}$ This effect however loses economic and statistical significance among lower-caste applicants when we focus on the discontinuity sample (Models 5 and 6).

${ }^{32}$ Again, the effect loses statistical (Models 5 and 6) and economic (Model 6) significance for lower-caste applicants in the discontinuity sample. 
In the remaining rows of Table 10, we study the impact of attending engineering school on whether one works in the private sector, works in the public sector, is self-employed, or works in a family business. ${ }^{33}$ Both lower- and upper-caste members see their likelihood of being self-employed or working in a family business decline by about the same amount (10 percentage points) after attending engineering college. Most of the extra employment generated among general-caste members is in the private sector. For lower-caste members, the point estimates indicate higher employment in both the private and government sectors, but these estimates are very noisy. The growth in public-sector employment, however, suggests that part of the positive employment effects of attending engineering college for lower-caste candidates may be linked to other affirmative action programs in the labor market.

Finally, Table 11 studies whether and how attending engineering college affects one’s social networks and other variables such one’s self-reported level of civic engagement, social identity, and attitudes towards affirmative action programs, as defined in Section III and Table 3. The first variable we examine is whether a given individual used friends and family to find his or her current or last job. Interestingly, among upper-caste candidates, having attended engineering school appears to be a substitute for relying on social networks when searching for a job; we find no such substitution pattern in the lower-caste groups. Controlling for all background characteristics (Model 4), the difference in the coefficients between the upper- and lower-caste groups is significant at the 5 percent level. There are many possible interpretations for this finding. One possibility is that upper-caste applicants can compensate for the lack of a good education by relying on well-connected friends and family members to find a job, but that this compensation mechanism does not exist for lower-caste applicants. Another possibility is that lower-caste applicants derive value from the assistance of well-connected friends and family members in their job search, even when they have attended engineering school, maybe because their educational background carries less weight among employers.

Next, we examine whether attending engineering school changes the strength of one's caste identity. We find no meaningful effect; the point estimates are negative across all regressions and panels, indicating weaker caste identity among those who attended engineering college, but none of the estimated coefficients reach standard levels of statistical significance.

\footnotetext{
33 The missing category is "working for an NGO."
} 
In the next four rows of Table 11, we study respondents' opinions towards various affirmative action programs. Overall, among general-caste respondents, we do not find much systematic difference in opinions between the candidates who attended engineering college and those who did not. So, in particular, it does not appear that those who are denied a seat in an engineering college due to the affirmative action program end up expressing more negative attitudes towards these programs. While still quite mixed, we find somewhat more compelling evidence of higher support for reservation policies among the lower-caste applicants who got to attend engineering school. Surprisingly, though, what appears to drive this higher support is a more favorable attitude towards reservation policies for females, and especially reservation policies for females in engineering schools; in contrast, we find no robust evidence that the lower-caste applicants who were offered a seat in an engineering college end up expressing more (or less) support for the specific reservation program that let them into college.

Finally, in the last row of Table 11, we investigate possible effects on civic engagement. Recall that "participates in government" is a variable that captures whether the individual voted in the last election or donated money to a political party. All but one of the point estimates are negative, but none are statistically significant.

Overall, Table 11 indicates little robust effect of going to engineering college on one's caste attitude, opinions towards affirmative action programs, or level of civic engagement. While the existence of affirmative action for minorities in engineering schools may shift overall attitudes towards caste or other affirmative action policies, we do not find strong differential shifts between those who were above or below the admission threshold in their caste category. Specifically, we find little evidence that the upper-caste group members who "lose out" due to these programs end up with more negative attitudes towards lower castes or more negative attitudes towards affirmative action programs. At best, there might be some sign of a more favorable attitude towards the reservation policies among those lower-caste candidates who directly experienced the benefit of these policies.

\section{Conclusion}

Our analysis suggests that the affirmative action policy redistributes resources to minority groups. Contrary to the arguments of some critics, the policy does not merely crowd out economically-disadvantaged upper-caste students to make way for economically-advantaged lower-caste students. The individuals who are displaced by the program come from stronger socio-economic backgrounds than the displacers. Hence, by targeting disadvantaged caste 
groups, the policy achieves some income targeting without generating any of the behavioral distortions typically associated with income targeting. Moreover, despite their low test scores, the marginal admits from lower castes earned significant returns from attending engineering college. In other words, our findings do not support the view that the academic resources that are devoted to the lower-caste students are totally wasted on them.

However, we also identify efficiency costs of the program and limitations to its ability to redistribute. First, like other redistributive programs, the affirmative action policy comes at an economic cost in that the marginal lower-caste admit experiences a smaller income increase than the increase that would have been experienced by the marginal general-caste admit. In this particular context, we find that for 1 Rupee lost to the upper caste, the lowercaste members gain 0.4 to 0.6 Rs (using the point estimates from our preferred specifications in Table 7). Second, and most troublesome, our results suggest that among the lower-caste admits, it is those from stronger socioeconomic backgrounds who benefit most from the reservation policy. This result somewhat weakens the case that the policy benefits the economically disadvantaged.

This study contributes to the literature on affirmative action by taking advantage of both a straightforward policy experiment and a comprehensive dataset that provides information not only on the individuals who obtained admissions to higher education due to affirmative action, but also on those who were denied admissions as a result of affirmative action. Our findings also offer clear directions for future work. First, our analysis focuses on educational reservations in one state and one field (engineering). We see great value in replications of this research in other educational fields and other regions: relationships between advantaged and disadvantaged groups vary greatly across regions, and the nature of the educational production function may also vary significantly across fields. Second, our research suggests the economic and redistributive trade-offs that are involved in affirmative action. Future research should be prepared to further understand these social costs, and to compare affirmative action policies to other approaches with similar social objectives. 


\section{Works Cited}

Alon, Sigal, and Marta Tienda. “Assessing the 'Mismatch' Hypothesis: Differentials in College Graduation Rates by Institutional Selectivity,” Sociology of Education, 78 (2005): 294-315.

Arcidiacono, Peter. "Affirmative Action in Higher Education: How do Admission and Financial Aid Rules Affect Future Earnings?” Econometrica, 73 (2005): 1477-1524.

Baley, Susan. "Caste, Society and Politics in India from the Eighteenth Century to the Modern Age," The New Cambridge History of India, Volume IV, Cambridge: Cambridge University Press: 1999

Bowen, William G., and Derek Bok . The Shape of the River: Long-Term Consequences of Considering Race in College and University Admissions. Princeton, NJ: Princeton University Press, 1998.

Das, Bhagwan. "Moments in a History of Reservations,” Economic and Political Weekly, (2000): 3831-3834.

de Zwart, Frank. "Practical Knowledge and Institutional Design in India's Affirmative Action Policy," Anthropology Today, 16 (2000): 4-7.

de Zwart, Frank. "The Logic of Affirmative Action: Caste, Class and Quotas in India," Acta Sociologica, 43 (2000): 235-249.

Falaris, Evangelos M. “The Effect of Survey Attrition in Longitudinal Surveys: Evidence from Peru, Côte d'Ivoire and Vietnam,” Journal of Development Economics, 70 (2003): 133-157.

Fitzgerald, John, Peter Gottschalk, and Robert Moffitt. “An Analysis of Sample Attrition in Panel Data: The Michigan Panel Study of Income Dynamics,” Journal of Human Resources, 33 (1998): 251-299.

Fryer, Roland G., Glenn C. Loury and Tolga Yuret. (2003). “Color-Blind Affirmative Action,” NBER WP. No. 10103.

Fryer, Roland G., and Glenn C. Loury. “Affirmative Action and Its Myths,” Journal of Economic Perspectives, 19 (2005): 16-28.

Herrnstein, Richard J., and Charles A. Murray. The Bell Curve: Intelligence and Class Structure in American Life, New York: The Free Press, 1994.

Harry Holzer; David Neumark, “Assessing Affirmative Action,” Journal of Economic Literature, 38 (2000): 483568.

Kane, Thomas J. "Racial and Ethnic Preferences in College Admissions," The Black-White Test Score Gap, edited by Christopher Jencks and Meredith Phillips, Washington D.C.: Brookings Institution Press, 1998.

Kumar, Dharma. “The Affirmative Action Debate in India,” Asian Survey, 32 (1992): 290-302.

Loury, Linda Datcher \& Garman, David. "Affirmative Action in Higher Education," American Economic Review83 (1993):99-103.

Osborne, Evan. “Culture, Development and Government: Reservations in India," Economic Development and Cultural Change, 49 (2006): 659-685.

Munshi, Kaivan and Mark Rosenzweig. "Traditional Institutions Meet the Modern World: Caste, Gender, and Schooling Choice in a Globalizing Economy,” American Economic Review. 96 (2006): 1225-1252. 
Pande, Rohini. "Can Mandated Political Representation Provide Disadvantaged Minorities Policy Influence? Theory and Evidence from India,” American Economic Review, 93 (2003):1132-1151.

Rothstein, Jesse and Albert H. Yoon (2007), “Mismatch in Law School” working paper.

Rothstein, Jesse and Albert H. Yoon (2007), “Affirmative Action in Law School Admissions: What Do Racial Preferences Do?”, MIMEO.

Sowell, Thomas. “Are Quotas Good for Blacks?” Commentary, 65 (1978): 39-43.

Thernstrom, Stephan, and Abigail M. Thernstrom. America in Black and White: One Nation, Indivisible, New York: Simon \& Schuster, 1997.

Wolpert, Stanley, Editor in Chief. Encyclopedia of India. Thomson Gale, 2006 
Figure 1: Score on Admissions Exam in 1996, by Category

\section{A. Upper Caste Groups}

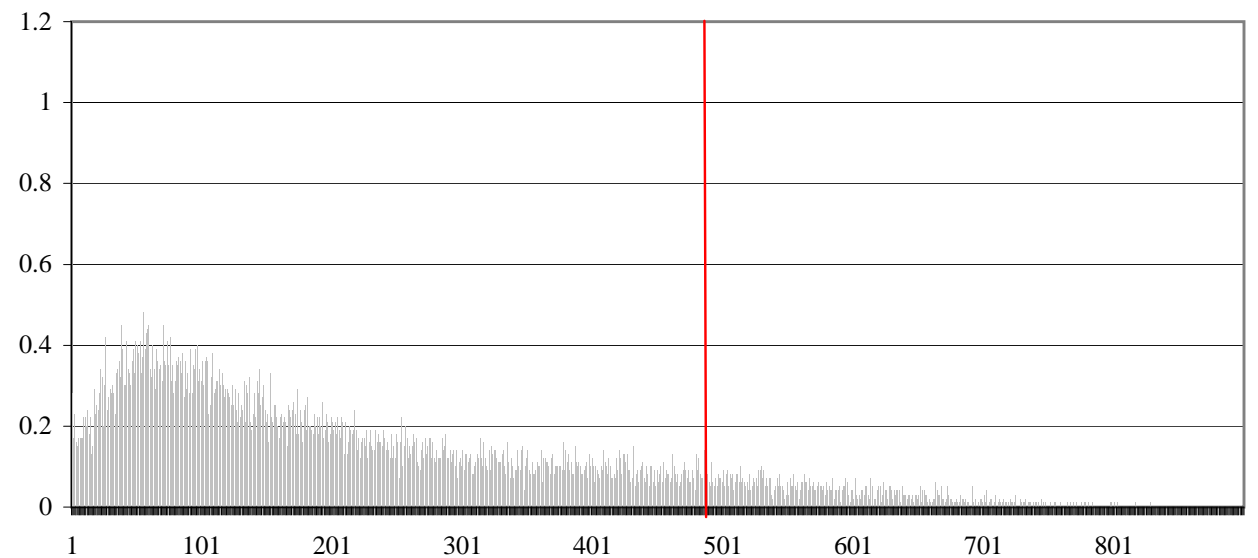

B. Other Backward Castes

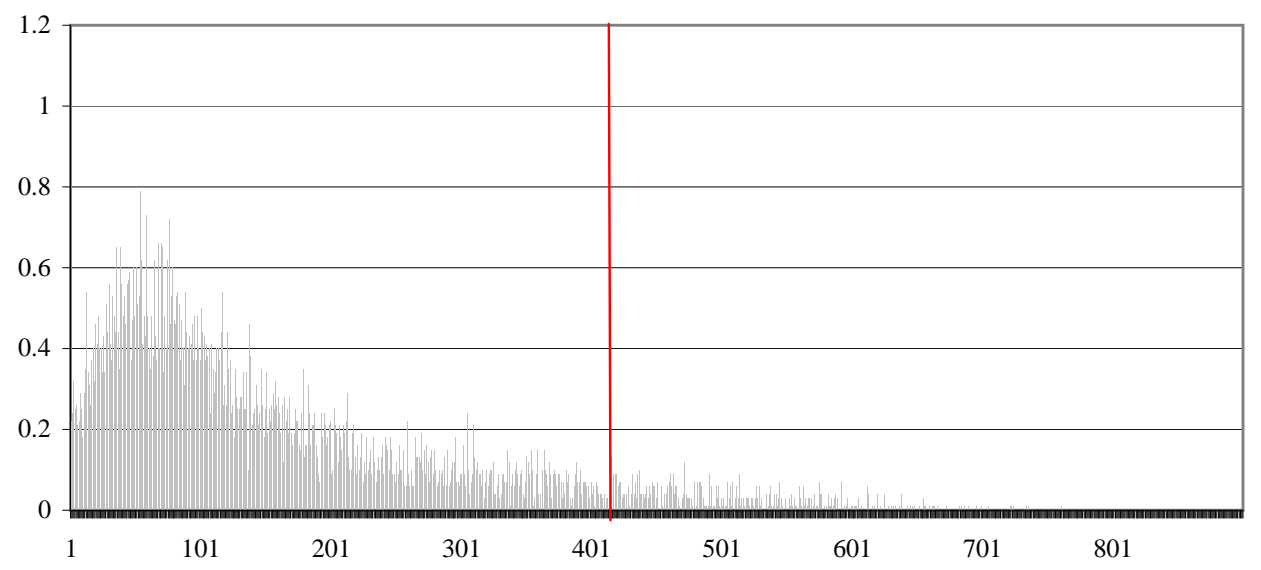

\section{Scheduled Castes}

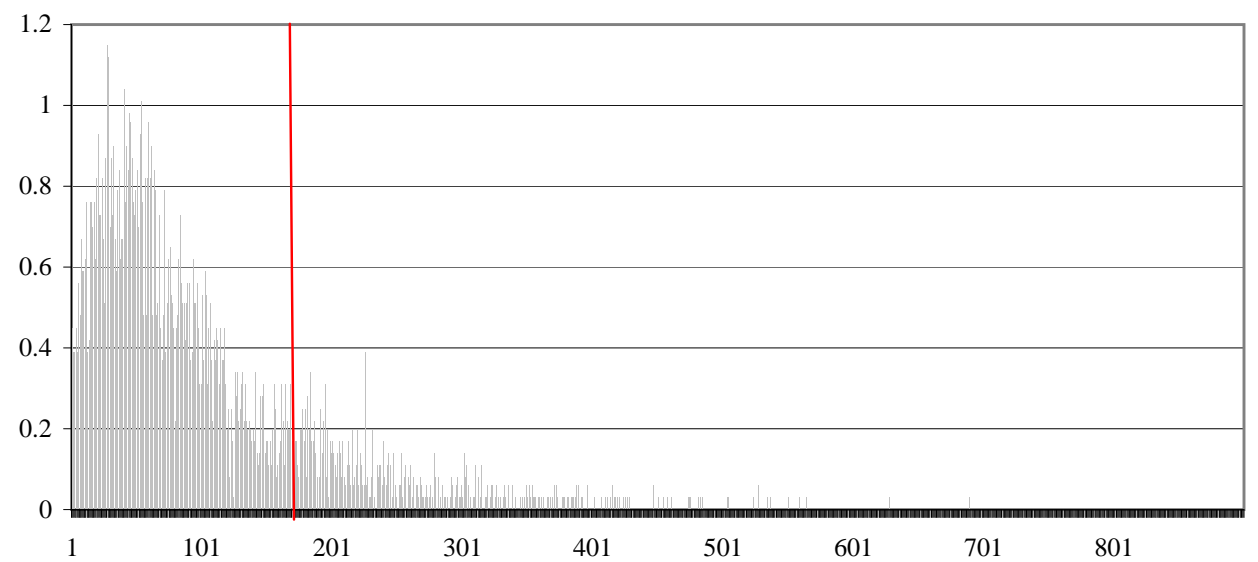

Notes:

1. The figures provide the distribution of test scores for applicants to engineering colleges in 1996, by caste group. 
Figure 2: Percentage of Applicants Who Attended Engineering University in 1996, by Score and Category

A. Upper Caste Groups

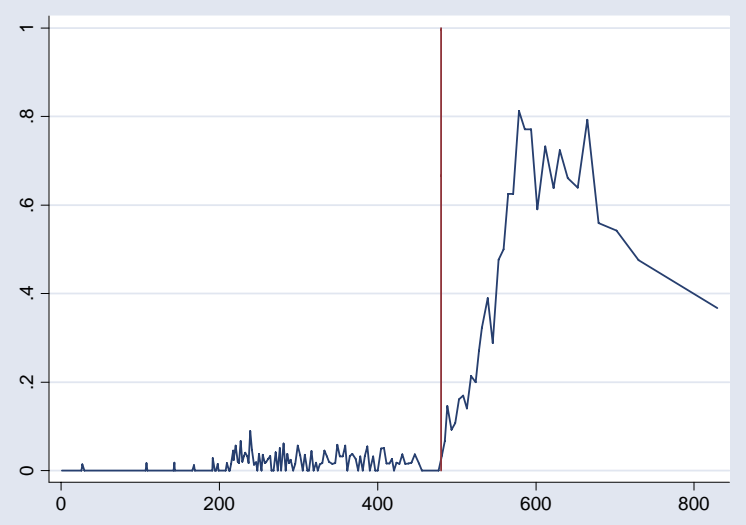

B. Other Backward Castes

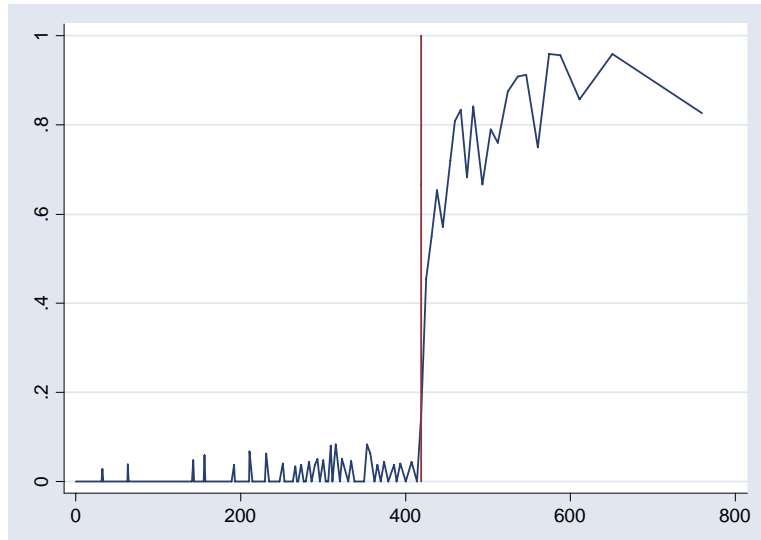

C. Scheduled Castes

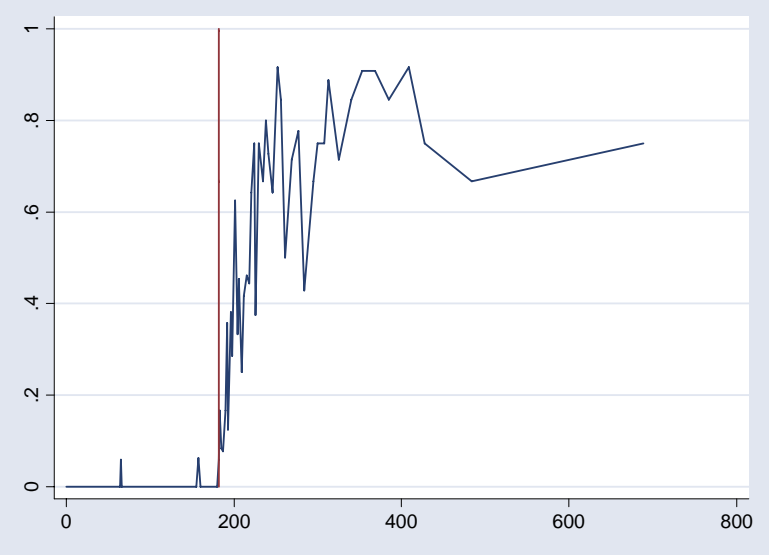

Notes:

1. The figures graph the percentage of applicants who attended engineering college in 1996 by test score for each caste group. 
Table 1A: Comparing Pre-Characteristics Across Groups

\begin{tabular}{|c|c|c|c|c|c|c|c|}
\hline & \multicolumn{4}{|c|}{ Means } & \multicolumn{3}{|c|}{ Comparison of Means (p-value) } \\
\hline & $\begin{array}{c}\text { Full Sample } \\
(1)\end{array}$ & $\begin{array}{c}\text { Upper Caste } \\
(2)\end{array}$ & $\begin{array}{l}\mathrm{OBC} \\
(3)\end{array}$ & $\begin{array}{l}\text { SC } \\
(4) \\
\end{array}$ & $\begin{array}{c}\text { UC Vs OBC } \\
(5)\end{array}$ & $\begin{array}{c}\text { UC Vs SC } \\
(6)\end{array}$ & $\begin{array}{c}\text { OBC Vs SC } \\
(7)\end{array}$ \\
\hline \multicolumn{8}{|c|}{ A. Characteristics of Main Income Earner in Family in 1996} \\
\hline Below Graduate Degree & 0.36 & 0.21 & 0.43 & 0.53 & $0.00 * * *$ & $0.00 * * *$ & $0.08 *$ \\
\hline Above Master's Degree & 0.21 & 0.30 & 0.16 & 0.13 & $0.00 * * *$ & $0.00 * * *$ & 0.46 \\
\hline Employed & 0.97 & 0.97 & 0.97 & 0.98 & 0.83 & 0.49 & 0.65 \\
\hline Income & 10324.77 & 12790.86 & 8947.84 & 8081.25 & $0.00 * * *$ & $0.00 * * *$ & 0.26 \\
\hline Log(Income) & 9.02 & 9.26 & 8.90 & 8.78 & $0.00 * * *$ & $0.00 * * *$ & $0.08 *$ \\
\hline Engineer & 0.13 & 0.13 & 0.14 & 0.08 & 0.51 & 0.27 & $0.08 *$ \\
\hline Uses Computer in Job & 0.11 & 0.14 & 0.10 & 0.07 & 0.23 & $0.03 * *$ & 0.31 \\
\hline Number of other children & 2.69 & 2.33 & 2.76 & 3.21 & $0.00 * * *$ & $0.00 * * *$ & $0.00 * * *$ \\
\hline \multicolumn{8}{|c|}{ B. Characteristics of Engineering Applicant } \\
\hline Attended an English Private School & 0.50 & 0.63 & 0.45 & 0.32 & $0.00 * * *$ & $0.00 * * *$ & $0.01^{* *}$ \\
\hline Attended a Government School & 0.17 & 0.11 & 0.14 & 0.28 & 0.44 & $0.00 * * *$ & $0.00 * * *$ \\
\hline Age & 18.51 & 18.20 & 18.52 & 18.98 & $0.00 * * *$ & $0.00 * * *$ & $0.00 * * *$ \\
\hline Male & 0.84 & 0.80 & 0.89 & 0.86 & $0.00 * * *$ & $0.06 * *$ & 0.32 \\
\hline & \multicolumn{4}{|c|}{ Means } & \multicolumn{3}{|c|}{ Comparison of Means (p-value) } \\
\hline & $\begin{array}{c}\text { Full Sample } \\
\text { (1) }\end{array}$ & $\begin{array}{c}\text { Upper Caste } \\
(2)\end{array}$ & $\begin{array}{l}\text { OBC } \\
(3) \\
\end{array}$ & $\begin{array}{l}\text { SC } \\
(4) \\
\end{array}$ & $\begin{array}{c}\text { UC Vs OBC } \\
(5)\end{array}$ & $\begin{array}{c}\text { UC Vs SC } \\
(6) \\
\end{array}$ & $\begin{array}{c}\text { OBC Vs SC } \\
(7)\end{array}$ \\
\hline HH Below Graduate Degree & 0.80 & 0.70 & 0.89 & 0.94 & $0.00 * * *$ & $0.00 * * *$ & $0.00 * * *$ \\
\hline HH Works Regularly & 0.81 & 0.81 & 0.81 & 0.79 & 0.96 & 0.26 & 0.28 \\
\hline Monthly Consumption Expenditures & 3452.04 & 4009.11 & 2995.30 & 2491.95 & $0.00 * * *$ & $0.00 * * *$ & $0.00 * * *$ \\
\hline HH Engineer & 0.01 & 0.02 & 0.01 & 0.00 & $0.01^{* *}$ & $0.02^{* *}$ & 0.48 \\
\hline $\mathrm{N}$ & 2911 & 1518 & 977 & 416 & 1393 & 977 & 1393 \\
\hline
\end{tabular}

Notes:

1. Table 1A reports the mean background characterics of the applicants and their families in 1996.

2. Table $1 \mathrm{~B}$ reports the mean background characteristics of a random sample of housheolds who live in urban areas of the state of India where our study occurs. The data for this table comes from the National Sample Survey of India, 55th Round.

3. Column 1 presents the mean for the full sample, while columns 2 - 3 report the means by caste groups. Columns 5 - 7 present p-values for the difference in means between each of the indicated groups.

4. Significance at $10 \%$ level is represented by a *, at the $5 \%$ level by a ** and at the $1 \%$ level by ***. 
Table 2: Comparing the Displaced with the Displacing

\begin{tabular}{|c|c|c|c|c|c|c|}
\hline & \multicolumn{3}{|c|}{$50 \%$ Yield } & \multicolumn{3}{|c|}{$70 \%$ Yield } \\
\hline & $\begin{array}{l}\text { Mean for } \\
\text { Displaced } \\
\text { (1) }\end{array}$ & $\begin{array}{l}\text { Mean for } \\
\text { Displacing } \\
\text { (2) }\end{array}$ & $\begin{array}{l}\text { p-value of } \\
\text { difference in } \\
\text { means } \\
\text { (3) }\end{array}$ & $\begin{array}{c}\text { Mean for } \\
\text { Displaced } \\
\text { (4) }\end{array}$ & $\begin{array}{l}\text { Mean for } \\
\text { Displacing } \\
\text { (5) }\end{array}$ & $\begin{array}{l}\mathrm{p} \text {-value of } \\
\text { difference in } \\
\text { means } \\
\text { (6) }\end{array}$ \\
\hline \multicolumn{7}{|c|}{ A. Characteristics of Main Income Earner in Family in 1996} \\
\hline Below Graduate Degree & 0.37 & 0.48 & 0.19 & 0.24 & 0.47 & 0.07 \\
\hline Above Master's Degree & 0.23 & 0.13 & 0.12 & 0.41 & 0.14 & $0.01 * * *$ \\
\hline Employed & 0.97 & 0.98 & 0.73 & 1.00 & 0.97 & 0.47 \\
\hline Income & 11098.28 & 7908.05 & $0.01 * *$ & 14088.24 & 8340.00 & $0.00^{* * *}$ \\
\hline Log(Income) & 9.07 & 8.82 & $0.02 * *$ & 9.33 & 8.87 & $0.00^{* * *}$ \\
\hline Engineer & 0.08 & 0.07 & 0.92 & 0.11 & 0.10 & 0.92 \\
\hline Uses Computer in Job & 0.05 & 0.06 & 0.85 & 0.06 & 0.09 & 0.64 \\
\hline Number of other chlidren & 2.49 & 3.18 & $0.01^{* * *}$ & 1.76 & 3.16 & $0.00^{* * *}$ \\
\hline \multicolumn{7}{|c|}{ B. Characteristics of Engineering Applicant } \\
\hline Attended an English Private School & 0.54 & 0.33 & $0.01 * *$ & 0.59 & 0.35 & $0.07 *$ \\
\hline Attended a Government School & 0.07 & 0.28 & $0.00^{* * *}$ & 0.00 & 0.27 & $0.02 * *$ \\
\hline Age & 18.25 & 18.76 & $0.02 * *$ & 18.16 & 18.73 & 0.11 \\
\hline Male & 0.73 & 0.84 & $0.10^{*}$ & 0.74 & 0.87 & 0.15 \\
\hline
\end{tabular}

Notes:

1. This table compares mean background characteristics of individuals displaced by affirmative action polices ("displaced") and with the mean for those who gained admissions due to affirmative action police ("displacing").

2. The sample only consists of those who were displaced or those who did the displacing. Columns 1- 3 assume a 50\% percent rate of acceptance of an admissions offer, providing a total sample size of 159 . Column 1 presents the mean for the displaced, while column 2 reports the mean for the displacing. Column 3 presents the p-value of the difference in means. Columns 4-6 replicate Columns 1-3, assuming a $70 \%$ yield $(\mathrm{N}=132)$.

3. Significance at $10 \%$ level is represented by a *, at the $5 \%$ level by a ** and at the $1 \%$ level by ***. 
Table 3: Mean of Outcomes, By Category

\begin{tabular}{|c|c|c|c|c|c|c|}
\hline & \multicolumn{5}{|c|}{ Means } & \multirow{3}{*}{$\begin{array}{c}\text { Comparison of } \\
\text { Means (p-value) } \\
\text { Upper vs. Lower } \\
(6)\end{array}$} \\
\hline & \multirow[b]{2}{*}{$\begin{array}{c}\text { Full Sample } \\
\text { (1) }\end{array}$} & \multirow[b]{2}{*}{$\begin{array}{c}\text { Upper Caste } \\
\text { (2) }\end{array}$} & \multicolumn{3}{|c|}{ Lower Caste Groups } & \\
\hline & & & $\begin{array}{c}\text { Total } \\
(3)\end{array}$ & $\begin{array}{c}\mathrm{OBC} \\
(4)\end{array}$ & $\begin{array}{l}\mathrm{SC} \\
(5)\end{array}$ & \\
\hline \multicolumn{7}{|c|}{ A. Employment and Income } \\
\hline \multirow[t]{3}{*}{ Employed } & 0.74 & 0.81 & 0.69 & 0.79 & 0.58 & $0.00 * * *$ \\
\hline & $(0.44)$ & $(0.39)$ & $(0.46)$ & $(0.41)$ & $(0.49)$ & \\
\hline & 721 & 308 & 413 & 213 & 200 & \\
\hline \multirow[t]{3}{*}{ Income } & 12637.22 & 17706.02 & 8995.69 & 12361.04 & 5630.35 & $0.00 * * *$ \\
\hline & $(14055.61)$ & (15988.59) & $(11162.42)$ & (12844.89) & $(7880.14)$ & \\
\hline & 653 & 273 & 380 & 190 & 190 & \\
\hline \multirow[t]{3}{*}{ Log(Income) } & 6.79 & 7.71 & 6.13 & 7.24 & 5.02 & $0.00 * * *$ \\
\hline & (4.34) & $(4.06)$ & $(4.41)$ & $(4.04)$ & $(4.50)$ & \\
\hline & 653 & 273 & 380 & 190 & 190 & \\
\hline \multicolumn{7}{|c|}{ B. Employment Characteristics } \\
\hline \multirow[t]{3}{*}{ Works as Engineer } & 0.41 & 0.47 & 0.37 & 0.46 & 0.28 & $0.01^{* * *}$ \\
\hline & $(0.49)$ & $(0.50)$ & $(0.48)$ & $(0.50)$ & $(0.45)$ & \\
\hline & 716 & 306 & 410 & 211 & 199 & \\
\hline \multirow[t]{3}{*}{ Works in Government Sector } & 0.13 & 0.09 & 0.16 & 0.14 & 0.20 & $0.01 * * *$ \\
\hline & $(0.34)$ & $(0.29)$ & $(0.37)$ & $(0.34)$ & $(0.40)$ & \\
\hline & 719 & 306 & 413 & 213 & 200 & \\
\hline \multirow[t]{3}{*}{ Works in Private Sector } & 0.46 & 0.57 & 0.37 & 0.47 & 0.27 & $0.00 * * *$ \\
\hline & $(0.50)$ & $(0.50)$ & $(0.48)$ & $(0.50)$ & $(0.45)$ & \\
\hline & 719 & 306 & 413 & 213 & 200 & \\
\hline \multirow[t]{3}{*}{ Self-Employed/Family-Employed } & 0.05 & 0.04 & 0.06 & 0.08 & 0.05 & 0.11 \\
\hline & $(0.22)$ & $(0.19)$ & $(0.24)$ & $(0.26)$ & $(0.22)$ & \\
\hline & 719 & 306 & 413 & 213 & 200 & \\
\hline \multirow[t]{3}{*}{ Uses Computer in Job } & 0.51 & 0.65 & 0.43 & 0.58 & 0.31 & $0.00 * * *$ \\
\hline & $(0.50)$ & $(0.48)$ & $(0.50)$ & $(0.50)$ & $(0.46)$ & \\
\hline & 400 & 146 & 254 & 120 & 134 & \\
\hline \multirow[t]{3}{*}{ Uses English in Job } & 0.41 & 0.57 & 0.31 & 0.40 & 0.24 & $0.00 * * *$ \\
\hline & $(0.49)$ & $(0.50)$ & $(0.46)$ & $(0.49)$ & $(0.43)$ & \\
\hline & 407 & 150 & 257 & 121 & 136 & \\
\hline \multirow[t]{3}{*}{ Strongly Agrees--Views Job as Successful } & 1.75 & 2.04 & 1.58 & 2.01 & 1.20 & $0.03 * *$ \\
\hline & $(2.05)$ & $(2.14)$ & (1.99) & $(2.16)$ & $(1.75)$ & \\
\hline & 407 & 150 & 257 & 121 & 136 & \\
\hline
\end{tabular}

Notes:

1. This table reports mean outcome variables, by caste group. Standard deviations are in parenthesis; the sample size for each variable is listed below each mean and standard deviation.

2. Column 1 reports the mean for the full sample. Column 2 reports the mean for the upper caste caste groups. Column 3 presents the mean outcomes for the pooled lower caste groups, while column 4 and 5 report the means for the two main lower caste categories, OBC and SC respectively. Column 6 reports the p-value of the difference in means between the upper and lower caste groups.

3. The measure "Strongly agrees—views job as successful" is an index where one point is assigned for each of the following statements with which the individual strong agrees: The chances of promotion at work are good, promotions are handled fairly, the people at work take a personal interest in me, working in groups is important in getting work done right, my supervisor is helpful in getting the job done, and overall I am satisfied with the work environment. "Participates in government" is an indicator variable for whether the individual has voted in the last election or donated money to a political party. According to this measure, there is a higher level of civic engagement in the minority groups than in the non-minority group. The variable "Index of caste category" is a categorical variable that is defined as the sum of the following 0/1 variables: belongs to BJP (a Hindu Nationalist Political Party), attends religious activity at least once a month, donates to religious organizations, and belongs to caste association. The "Reservations Index" is a categorical variable that is the sum of $0 / 1$ variables on reservations listed in the table.

4. Significance at $10 \%$ level is represented by a *, at the $5 \%$ level by a ** and at the $1 \%$ level by ***. 
Table 3: Mean of Outcomes, By Category (Continued)

\begin{tabular}{|c|c|c|c|c|c|c|}
\hline & \multicolumn{5}{|c|}{ Means } & \multirow{3}{*}{$\begin{array}{c}\text { Comparison of } \\
\text { Means (p-value) } \\
\text { Upper vs. Lower } \\
(6)\end{array}$} \\
\hline & \multirow[b]{2}{*}{$\begin{array}{l}\text { Full Sample } \\
(1)\end{array}$} & \multirow[b]{2}{*}{$\begin{array}{c}\text { Upper Caste } \\
(2) \\
\end{array}$} & \multicolumn{3}{|c|}{ Lower Caste Groups } & \\
\hline & & & $\begin{array}{c}\text { Total } \\
(3)\end{array}$ & $\begin{array}{c}\text { OBC } \\
(4)\end{array}$ & $\begin{array}{l}\mathrm{SC} \\
(5) \\
\end{array}$ & \\
\hline \multicolumn{7}{|c|}{ C. Social Networks and Beliefs } \\
\hline \multirow[t]{3}{*}{ Family or Friends Helped Find Job } & 0.10 & 0.11 & 0.09 & 0.12 & 0.07 & 0.64 \\
\hline & $(0.30)$ & $(0.31)$ & $(0.29)$ & $(0.33)$ & $(0.25)$ & \\
\hline & 706 & 304 & 402 & 206 & 196 & \\
\hline \multirow[t]{3}{*}{ Participates in Government } & 0.78 & 0.69 & 0.83 & 0.79 & 0.88 & $0.00 * * *$ \\
\hline & $(0.42)$ & $(0.47)$ & $(0.37)$ & $(0.41)$ & $(0.33)$ & \\
\hline & 407 & 150 & 257 & 121 & 136 & \\
\hline \multirow[t]{3}{*}{ Index of Caste Identity } & 1.10 & 0.98 & 1.16 & 1.20 & 1.13 & $0.05^{*}$ \\
\hline & $(0.93)$ & $(0.89)$ & $(0.95)$ & $(0.97)$ & $(0.93)$ & \\
\hline & 407 & 150 & 257 & 121 & 136 & \\
\hline \multirow{3}{*}{ Reservation Index } & 1.58 & 1.22 & 1.79 & 1.53 & 2.02 & $0.00 * * *$ \\
\hline & (1.21) & (1.14) & (1.19) & (1.19) & (1.15) & \\
\hline & 383 & 137 & 246 & 116 & 130 & \\
\hline \multirow{3}{*}{$\begin{array}{l}\text { Agrees with Reservations for Females in } \\
\text { Government }\end{array}$} & 0.61 & 0.52 & 0.66 & 0.59 & 0.72 & $0.01 * * *$ \\
\hline & $(0.49)$ & $(0.50)$ & $(0.48)$ & $(0.49)$ & $(0.45)$ & \\
\hline & 383 & 137 & 246 & 116 & 130 & \\
\hline \multirow{3}{*}{$\begin{array}{l}\text { Agrees with Reservations for Females in } \\
\text { Engineering Universities }\end{array}$} & 0.52 & 0.40 & 0.58 & 0.51 & 0.64 & $0.00 * * *$ \\
\hline & $(0.50)$ & $(0.49)$ & $(0.49)$ & $(0.50)$ & $(0.48)$ & \\
\hline & 389 & 141 & 248 & 117 & 131 & \\
\hline \multirow{3}{*}{$\begin{array}{l}\text { Reservations for Minorities in Engineering } \\
\text { Universities Fair }\end{array}$} & 0.46 & 0.30 & 0.55 & 0.42 & 0.66 & $0.00 * * *$ \\
\hline & $(0.50)$ & $(0.46)$ & $(0.50)$ & $(0.50)$ & $(0.47)$ & \\
\hline & 385 & 141 & 244 & 116 & 128 & \\
\hline
\end{tabular}

Notes:

1. This table reports mean outcome variables, by caste group. Standard deviations are in parenthesis; the sample size for each variable is listed below each mean and standard deviation.

2. Column 1 reports the mean for the full sample. Column 2 reports the mean for the upper caste caste groups. Column 3 presents the mean outcomes for the pooled lower caste groups, while column 4 and 5 report the means for the two main lower caste categories, OBC and SC respectively. Column 6 reports the p-value of the difference in means between the upper and lower caste groups.

3. The measure "Strongly agrees—views job as successful" is an index where one point is assigned for each of the following statements with which the individual strong agrees: The chances of promotion at work are good, promotions are handled fairly, the people at work take a personal interest in me, working in groups is important in getting work done right, my supervisor is helpful in getting the job done, and overall I am satisfied with the work environment. "Participates in government" is an indicator variable for whether the individual has voted in the last election or donated money to a political party. According to this measure, there is a higher level of civic engagement in the minority groups than in the non-minority group. The variable "Index of caste category" is a categorical variable that is defined as the sum of the following 0/1 variables: belongs to BJP (a Hindu Nationalist Political Party), attends religious activity at least once a month, donates to religious organizations, and belongs to caste association. The "Reservations Index" is a categorical variable that is the sum of $0 / 1$ variables on reservations listed in the table.

4. Significance at $10 \%$ level is represented by a *, at the $5 \%$ level by a ** and at the $1 \%$ level by $* * *$. 
Table 4: OLS Regressions - Labor Market Outcomes

\begin{tabular}{|c|c|c|c|c|c|c|c|c|}
\hline Outcome: & $\begin{array}{c}\text { Employed } \\
(1) \\
\end{array}$ & $\begin{array}{c}\text { Employed } \\
(2) \\
\end{array}$ & $\begin{array}{c}\text { Income } \\
(3) \\
\end{array}$ & $\begin{array}{c}\text { Income } \\
(4) \\
\end{array}$ & $\begin{array}{c}\text { Ln(Income) } \\
(5) \\
\end{array}$ & $\begin{array}{c}\text { Ln(Income) } \\
(6) \\
\end{array}$ & $\begin{array}{c}\text { Inc Below Med } \\
(7) \\
\end{array}$ & $\begin{array}{c}\text { Inc Below Med } \\
(8) \\
\end{array}$ \\
\hline $\begin{array}{l}\text { Panel A: Full Samp } \\
\text { went }\end{array}$ & $\begin{array}{l}0.06 \\
\quad(0.03)^{*}\end{array}$ & $\begin{array}{c}0.05 \\
(0.03)\end{array}$ & $\begin{array}{c}3904.06 \\
(1066.90)^{* * *}\end{array}$ & $\begin{array}{c}3292.12 \\
(1051.80)^{* * *}\end{array}$ & $\begin{array}{c}0.82 \\
(0.34)^{* *}\end{array}$ & $\begin{array}{c}0.69 \\
(0.35)^{* *}\end{array}$ & $\begin{array}{c}-0.12 \\
(0.04)^{* * *}\end{array}$ & $\begin{array}{c}-0.1 \\
(0.04)^{* * *}\end{array}$ \\
\hline $\begin{array}{l}\text { Observations } \\
\text { R-squared } \\
\end{array}$ & $\begin{array}{l}721 \\
0.09 \\
\end{array}$ & $\begin{array}{l}720 \\
0.11 \\
\end{array}$ & $\begin{array}{r}653 \\
0.17 \\
\end{array}$ & $\begin{array}{r}652 \\
0.26 \\
\end{array}$ & $\begin{array}{r}653 \\
0.11 \\
\end{array}$ & $\begin{array}{l}652 \\
0.14 \\
\end{array}$ & $\begin{array}{l}653 \\
0.17 \\
\end{array}$ & $\begin{array}{r}652 \\
0.22 \\
\end{array}$ \\
\hline $\begin{array}{l}\text { Panel B: Upper Cas } \\
\text { went }\end{array}$ & $\begin{array}{l}\text { ste Groups } \\
0.06 \\
(0.05)\end{array}$ & $\begin{array}{c}0.04 \\
(0.05)\end{array}$ & $\begin{array}{c}5337.69 \\
(2012.20)^{* * *}\end{array}$ & $\begin{array}{c}3685.44 \\
(2066.57)^{*}\end{array}$ & $\begin{array}{c}0.74 \\
(0.51)\end{array}$ & $\begin{array}{c}0.46 \\
(0.55)\end{array}$ & $\begin{array}{c}-0.15 \\
(0.06)^{* *}\end{array}$ & $\begin{array}{l}-0.09 \\
(0.06)\end{array}$ \\
\hline $\begin{array}{l}\text { Observations } \\
\text { R-squared } \\
\end{array}$ & $\begin{array}{r}308 \\
0.04 \\
\end{array}$ & $\begin{array}{l}308 \\
0.07 \\
\end{array}$ & $\begin{array}{l}273 \\
0.06 \\
\end{array}$ & $\begin{array}{l}273 \\
0.18 \\
\end{array}$ & $\begin{array}{l}273 \\
0.05 \\
\end{array}$ & $\begin{array}{l}273 \\
0.09 \\
\end{array}$ & $\begin{array}{l}273 \\
0.09 \\
\end{array}$ & $\begin{array}{l}273 \\
0.18 \\
\end{array}$ \\
\hline $\begin{array}{l}\text { Panel C: Lower Cas } \\
\text { went }\end{array}$ & $\begin{array}{l}\text { ste Groups( } \\
0.06 \\
(0.05)\end{array}$ & $\begin{array}{c}C \text { and } O B C) \\
0.05 \\
(0.05)\end{array}$ & $\begin{array}{c}3118.64 \\
(1133.88)^{* * *}\end{array}$ & $\begin{array}{c}2717.76 \\
(1105.12)^{* *}\end{array}$ & $\begin{array}{c}0.9 \\
(0.46)^{*}\end{array}$ & $\begin{array}{c}0.8 \\
(0.47)^{*}\end{array}$ & $\begin{array}{c}-0.11 \\
(0.05)^{* *}\end{array}$ & $\begin{array}{c}-0.09 \\
(0.05)^{*}\end{array}$ \\
\hline $\begin{array}{l}\text { Observations } \\
\text { R-squared } \\
\end{array}$ & $\begin{array}{l}413 \\
0.09 \\
\end{array}$ & $\begin{array}{l}412 \\
0.12 \\
\end{array}$ & $\begin{array}{l}380 \\
0.17 \\
\end{array}$ & $\begin{array}{r}379 \\
0.28 \\
\end{array}$ & $\begin{array}{l}380 \\
0.11 \\
\end{array}$ & $\begin{array}{l}379 \\
0.15 \\
\end{array}$ & $\begin{array}{l}380 \\
0.13 \\
\end{array}$ & $\begin{array}{l}379 \\
0.23 \\
\end{array}$ \\
\hline $\begin{array}{l}\text { Panel D: } O B C \\
\text { went }\end{array}$ & $\begin{array}{c}0.07 \\
(0.05)\end{array}$ & $\begin{array}{c}0.05 \\
(0.06)\end{array}$ & $\begin{array}{c}3678.43 \\
(1882.79)^{*}\end{array}$ & $\begin{array}{c}2290.94 \\
(1833.20)\end{array}$ & $\begin{array}{c}0.84 \\
(0.58)\end{array}$ & $\begin{array}{c}0.6 \\
(0.61)\end{array}$ & $\begin{array}{c}-0.18 \\
(0.07)^{* *}\end{array}$ & $\begin{array}{c}-0.13 \\
(0.07)^{*}\end{array}$ \\
\hline $\begin{array}{l}\text { Observations } \\
\text { R-squared }\end{array}$ & $\begin{array}{l}213 \\
0.15 \\
\end{array}$ & $\begin{array}{l}212 \\
0.24 \\
\end{array}$ & $\begin{array}{l}190 \\
0.12 \\
\end{array}$ & $\begin{array}{l}189 \\
0.33 \\
\end{array}$ & $\begin{array}{l}190 \\
0.15 \\
\end{array}$ & $\begin{array}{r}189 \\
0.25 \\
\end{array}$ & $\begin{array}{l}190 \\
0.09 \\
\end{array}$ & $\begin{array}{l}189 \\
0.31 \\
\end{array}$ \\
\hline $\begin{array}{l}\text { Panel E: SC } \\
\text { went }\end{array}$ & $\begin{array}{c}0.07 \\
(0.08)\end{array}$ & $\begin{array}{c}0.07 \\
(0.08)\end{array}$ & $\begin{array}{c}2962.11 \\
(1253.28)^{* *}\end{array}$ & $\begin{array}{c}3193.08 \\
(1280.55)^{* *}\end{array}$ & $\begin{array}{c}1.08 \\
(0.72)\end{array}$ & $\begin{array}{c}1.09 \\
(0.76)\end{array}$ & $\begin{array}{l}-0.04 \\
(0.07)\end{array}$ & $\begin{array}{l}-0.02 \\
(0.07)\end{array}$ \\
\hline $\begin{array}{l}\text { Observations } \\
\text { R-squared } \\
\end{array}$ & $\begin{array}{r}200 \\
0.04 \\
\end{array}$ & $\begin{array}{l}200 \\
0.1 \\
\end{array}$ & $\begin{array}{l}190 \\
0.07 \\
\end{array}$ & $\begin{array}{l}190 \\
0.18 \\
\end{array}$ & $\begin{array}{r}190 \\
0.05 \\
\end{array}$ & $\begin{array}{l}190 \\
0.11 \\
\end{array}$ & $\begin{array}{l}190 \\
0.06 \\
\end{array}$ & $\begin{array}{l}190 \\
0.17 \\
\end{array}$ \\
\hline $\begin{array}{l}\text { Individual Controls } \\
\text { Household Controls } \\
\text { City Fixed Effects }\end{array}$ & YES & $\begin{array}{l}\text { YES } \\
\text { YES } \\
\text { YES } \\
\end{array}$ & YES & $\begin{array}{l}\text { YES } \\
\text { YES } \\
\text { YES } \\
\end{array}$ & YES & $\begin{array}{l}\text { YES } \\
\text { YES } \\
\text { YES } \\
\end{array}$ & YES & $\begin{array}{l}\text { YES } \\
\text { YES } \\
\text { YES }\end{array}$ \\
\hline
\end{tabular}

Notes:

1. Each coefficient contains the result of a separate regression in which the dependent variable is either employed, income, log(income), or income below median, as indicated. The reported coefficient is on "went to engineering college."

2. In Panel A, the sample includes all individuals. The sample in Panel B includes upper caste applicants, while the sample in Panel C includes lower caste applicants. Panel D \& E disaggregate the minority groups by the two main categories (OBC and SC).

3. The individual-level controls are dummies for OBC and SC categories, a gender dummy, the logarithm of age, dummies for the type of secondary school attended (e.g. English private school, Hindi private school or government school), and controls for whether or not the outcome data comes from the parent or child survey. The household-level controls are household head monthly income as of 1996 (in Rs), dummies for the educational attainment of the household head, a dummy variable for whether the household head is an engineer, a dummy for whether or not the household head uses a computer at work, and the number of other children in the household.

4. Standard errors in parentheses. The number of observations and the $\mathrm{R}^{\wedge} 2$ of the regression are listed below the standard errors.

5. Significance at $10 \%$ level is represented by a *, at the $5 \%$ level by a ** and at the $1 \%$ level by ***. 
Table 5: Comparing Pre-characteristics for Applicants Above and Below Threshold, by Category

\begin{tabular}{|c|c|c|c|c|c|c|c|c|}
\hline \multirow[b]{3}{*}{$\begin{array}{l}\text { Sample: } \\
\text { Pre-characteristic }\end{array}$} & & & \multicolumn{6}{|c|}{ Lower Caste } \\
\hline & \multicolumn{2}{|c|}{ Upper Caste } & \multicolumn{2}{|c|}{ Total } & \multicolumn{2}{|c|}{ OBC } & \multicolumn{2}{|c|}{ Scheduled Caste } \\
\hline & $\begin{array}{r}\text { Full } \\
(1)\end{array}$ & $\begin{array}{l}\text { Disc } \\
\text { (2) }\end{array}$ & $\begin{array}{r}\text { Full } \\
\text { (3) }\end{array}$ & $\begin{array}{l}\text { Disc } \\
\text { (4) }\end{array}$ & $\begin{array}{l}\text { Full } \\
(5)\end{array}$ & $\begin{array}{l}\text { Disc } \\
\text { (6) }\end{array}$ & $\begin{array}{c}\text { Full } \\
(7)\end{array}$ & $\begin{array}{l}\text { Disc } \\
\text { (8) }\end{array}$ \\
\hline \multicolumn{9}{|c|}{ A. Characteristics of Main Income Earner in Family in 1996} \\
\hline Below Graduate Degree & $\begin{array}{l}-0.062 \\
(0.059)\end{array}$ & $\begin{array}{l}-0.077 \\
(0.084)\end{array}$ & $\begin{array}{l}-0.083 \\
(0.052)\end{array}$ & $\begin{array}{l}-0.082 \\
(0.074)\end{array}$ & $\begin{array}{l}-0.101 \\
(0.072)\end{array}$ & $\begin{array}{l}-0.081 \\
(0.103)\end{array}$ & $\begin{array}{l}-0.063 \\
(0.077)\end{array}$ & $\begin{array}{l}-0.083 \\
(0.159)\end{array}$ \\
\hline Above Master's Degree & $\begin{array}{c}0.015 \\
(0.056)\end{array}$ & $\begin{array}{c}-0.06 \\
(0.091)\end{array}$ & $\begin{array}{c}0.019 \\
(0.038)\end{array}$ & $\begin{array}{l}-0.046 \\
(0.056)\end{array}$ & $\begin{array}{c}0.061 \\
(0.054)\end{array}$ & $\begin{array}{l}-0.013 \\
(0.082)\end{array}$ & $\begin{array}{l}-0.027 \\
(0.052)\end{array}$ & $\begin{array}{l}-0.083 \\
(0.109)\end{array}$ \\
\hline Employed & $\begin{array}{c}-0.01 \\
(0.022)\end{array}$ & $\begin{array}{l}-0.018 \\
(0.022)\end{array}$ & $\begin{array}{l}-0.014 \\
(0.017)\end{array}$ & $\begin{array}{c}0.003 \\
(0.024)\end{array}$ & $\begin{array}{l}-0.006 \\
(0.025)\end{array}$ & $\begin{array}{c}0.006 \\
(0.035)\end{array}$ & $\begin{array}{l}-0.024 \\
(0.023)\end{array}$ & $\begin{array}{l}-0.001 \\
(0.047)\end{array}$ \\
\hline Income & $\begin{array}{c}708.857 \\
(1,359.592)\end{array}$ & $\begin{array}{c}842.545 \\
(2,258.617)\end{array}$ & $\begin{array}{c}724.411 \\
(769.800)\end{array}$ & $\begin{array}{c}-584.429 \\
(1,004.810)\end{array}$ & $\begin{array}{c}1,445.27 \\
(1,089.493)\end{array}$ & $\begin{array}{c}390.686 \\
(1,171.333)\end{array}$ & $\begin{array}{c}-20.336 \\
(1,087.590)\end{array}$ & $\begin{array}{c}-1,515.64 \\
(2,299.199)\end{array}$ \\
\hline Log(Income) & $\begin{array}{c}0.118 \\
(0.080)\end{array}$ & $\begin{array}{c}0.094 \\
(0.123)\end{array}$ & $\begin{array}{c}0.131 \\
(0.070)^{*}\end{array}$ & $\begin{array}{c}0.007 \\
(0.095)\end{array}$ & $\begin{array}{c}0.142 \\
(0.097)\end{array}$ & $\begin{array}{c}0.079 \\
(0.131)\end{array}$ & $\begin{array}{c}0.12 \\
(0.100)\end{array}$ & $\begin{array}{l}-0.059 \\
(0.210)\end{array}$ \\
\hline Engineer & $\begin{array}{c}0.023 \\
(0.041)\end{array}$ & $\begin{array}{c}0.006 \\
(0.118)\end{array}$ & $\begin{array}{c}0.024 \\
(0.031)\end{array}$ & $\begin{array}{c}0.022 \\
(0.040)\end{array}$ & $\begin{array}{c}0.047 \\
(0.048)\end{array}$ & $\begin{array}{c}0.025 \\
(0.064)\end{array}$ & $\begin{array}{c}0 \\
(0.039)\end{array}$ & $\begin{array}{c}0.018 \\
(0.081)\end{array}$ \\
\hline Uses Computer in Job & $\begin{array}{c}0.058 \\
(0.043)\end{array}$ & $\begin{array}{c}0.084 \\
(0.058)\end{array}$ & $\begin{array}{c}0.027 \\
(0.030)\end{array}$ & $\begin{array}{c}0.016 \\
(0.044)\end{array}$ & $\begin{array}{c}0.05 \\
(0.045)\end{array}$ & $\begin{array}{c}0.033 \\
(0.067)\end{array}$ & $\begin{array}{c}0.002 \\
(0.040)\end{array}$ & $\begin{array}{l}-0.002 \\
(0.083)\end{array}$ \\
\hline Number of Other Children & $\begin{array}{l}-0.134 \\
(0.130)\end{array}$ & $\begin{array}{l}-0.048 \\
(0.204)\end{array}$ & $\begin{array}{c}-0.12 \\
(0.152)\end{array}$ & $\begin{array}{c}0.067 \\
(0.222)\end{array}$ & $\begin{array}{c}-0.26 \\
(0.191)\end{array}$ & $\begin{array}{l}-0.222 \\
(0.256)\end{array}$ & $\begin{array}{c}0.036 \\
(0.242)\end{array}$ & $\begin{array}{c}0.371 \\
(0.492)\end{array}$ \\
\hline \multicolumn{9}{|c|}{ B. Characteristics of Engineering Applicant } \\
\hline Attended an English Private Schoo & $\begin{array}{c}0.058 \\
(0.060)\end{array}$ & $\begin{array}{c}0.102 \\
(0.092)\end{array}$ & $\begin{array}{c}0.052 \\
(0.051)\end{array}$ & $\begin{array}{c}0.033 \\
(0.075)\end{array}$ & $\begin{array}{c}0.096 \\
(0.073)\end{array}$ & $\begin{array}{c}0.06 \\
(0.105)\end{array}$ & $\begin{array}{c}0.003 \\
(0.072)\end{array}$ & $\begin{array}{c}0.004 \\
(0.149)\end{array}$ \\
\hline Attended a Government School & $\begin{array}{c}0.021 \\
(0.040)\end{array}$ & $\begin{array}{c}0.084 \\
(0.057)\end{array}$ & $\begin{array}{l}-0.006 \\
(0.042)\end{array}$ & $\begin{array}{l}-0.057 \\
(0.059)\end{array}$ & $\begin{array}{l}-0.023 \\
(0.051)\end{array}$ & $\begin{array}{l}-0.083 \\
(0.071)\end{array}$ & $\begin{array}{c}0.013 \\
(0.069)\end{array}$ & $\begin{array}{l}-0.029 \\
(0.143)\end{array}$ \\
\hline Age & $\begin{array}{l}-0.079 \\
(0.115)\end{array}$ & $\begin{array}{l}-0.054 \\
(0.202)\end{array}$ & $\begin{array}{l}-0.087 \\
(0.135)\end{array}$ & $\begin{array}{c}0.023 \\
(0.185)\end{array}$ & $\begin{array}{c}0.192 \\
(0.165)\end{array}$ & $\begin{array}{c}0.207 \\
(0.241)\end{array}$ & $\begin{array}{c}-0.38 \\
(0.214)^{*}\end{array}$ & $\begin{array}{l}-0.154 \\
(0.446)\end{array}$ \\
\hline Male & $\begin{array}{c}0.084 \\
(0.047)^{*}\end{array}$ & $\begin{array}{c}0.126 \\
(0.073)\end{array}$ & $\begin{array}{c}0.038 \\
(0.033)\end{array}$ & $\begin{array}{c}0.002 \\
(0.047)\end{array}$ & $\begin{array}{c}0.094 \\
(0.043)^{* *}\end{array}$ & $\begin{array}{c}0.081 \\
(0.061)\end{array}$ & $\begin{array}{c}-0.02 \\
(0.049)\end{array}$ & $\begin{array}{l}-0.075 \\
(0.103)\end{array}$ \\
\hline Chi-squared & 10.79 & 15.33 & 7.85 & 8.22 & 14.69 & 5.14 & 4.45 & 12.32 \\
\hline P-value & 0.37 & 0.12 & 0.55 & 0.61 & 0.14 & 0.88 & 0.92 & 0.26 \\
\hline
\end{tabular}

Notes:

1. Each cell contains the result of a separate regression in which the dependent variable is the pre-characteristic as indicated. The reported coefficient is on a dummy variable for "above cutoff." Standard errors are listed in parenthesis below the coefficient.

2. The sample in Column 1 is the full sample of upper caste groups. The sample in Column 2 is the discontinuity sample for upper caste groups where applicants with the top $25 \%$ test scores and the bottom $25 \%$ test scores are excluded from the sample. The remaining columns replicate Columns 1 - 2 for pooled lower caste groups (columns 3-4), the OBC (Columns 5-6), and the SC (Columns 7-8).

3. The Chi-squared and p-value of a SUR regression for joint significance are listed on the last two rows. Log(income) and Uses Computer in Job are excluded in order to be able to run the SUR model.

4. Significance at $10 \%$ level is represented by a *, at the $5 \%$ level by a ** and at the $1 \%$ level by ***. 
Table 6: First Stage Regressions

\begin{tabular}{|c|c|c|c|c|c|c|}
\hline & $\begin{array}{c}\text { Model } 1 \\
\text { (1) } \\
\end{array}$ & $\begin{array}{c}\text { Model } 2 \\
(2) \\
\end{array}$ & $\begin{array}{c}\text { Model } 3 \\
\text { (3) } \\
\end{array}$ & $\begin{array}{c}\text { Model } 4 \\
\text { (4) }\end{array}$ & $\begin{array}{c}\text { Model } 5 \\
\text { (5) }\end{array}$ & $\begin{array}{c}\text { Model } 6 \\
\text { (6) }\end{array}$ \\
\hline \multicolumn{7}{|c|}{ Panel A: Upper Caste Groups } \\
\hline Cutoff & $\begin{array}{c}0.51 \\
(0.05)^{* * *}\end{array}$ & $\begin{array}{c}0.53 \\
(0.05)^{* * *}\end{array}$ & $\begin{array}{c}0.54 \\
(0.05)^{* * *}\end{array}$ & $\begin{array}{c}0.53 \\
(0.05)^{* * *}\end{array}$ & $\begin{array}{c}0.4 \\
(0.08)^{* * *}\end{array}$ & $\begin{array}{c}0.43 \\
(0.09)^{* * *}\end{array}$ \\
\hline Observations & 308 & 308 & 308 & 308 & 154 & 154 \\
\hline$\underline{\text { R-squared }}$ & 0.27 & 0.29 & 0.32 & 0.35 & 0.13 & 0.24 \\
\hline \multicolumn{7}{|c|}{ Panel B: Lower Caste Groups (OBC and SC) } \\
\hline Cutoff & $\begin{array}{c}0.68 \\
(0.03) * * *\end{array}$ & $\begin{array}{c}0.68 \\
(0.03)^{* * *}\end{array}$ & $\begin{array}{c}0.68 \\
(0.03)^{* * *}\end{array}$ & $\begin{array}{c}0.68 \\
(0.03)^{* * *}\end{array}$ & $\begin{array}{c}0.56 \\
(0.05)^{* * *}\end{array}$ & $\begin{array}{c}0.54 \\
(0.05)^{* * *}\end{array}$ \\
\hline Observations & 413 & 413 & 412 & 412 & 210 & 209 \\
\hline R-squared & 0.52 & 0.53 & 0.54 & 0.54 & 0.4 & 0.48 \\
\hline \multicolumn{7}{|l|}{ Panel C: OBC } \\
\hline Cutoff & $\begin{array}{c}0.78 \\
(0.04)^{* * *}\end{array}$ & $\begin{array}{c}0.79 \\
(0.04)^{* * *}\end{array}$ & $\begin{array}{c}0.8 \\
(0.04)^{* * *}\end{array}$ & $\begin{array}{c}0.81 \\
(0.05)^{* * *}\end{array}$ & $\begin{array}{c}0.7 \\
(0.06)^{* * *}\end{array}$ & $\begin{array}{c}0.73 \\
(0.08)^{* * *}\end{array}$ \\
\hline Observations & 213 & 213 & 212 & 212 & 107 & 106 \\
\hline R-squared & 0.64 & 0.65 & 0.66 & 0.67 & 0.54 & 0.64 \\
\hline \multicolumn{7}{|l|}{ Panel D: SC } \\
\hline Cutoff & $\begin{array}{c}0.57 \\
(0.05)^{* * *}\end{array}$ & $\begin{array}{c}0.57 \\
(0.05)^{* * *}\end{array}$ & $\begin{array}{c}0.57 \\
(0.05)^{* * *}\end{array}$ & $\begin{array}{c}0.58 \\
(0.05)^{* * *}\end{array}$ & $\begin{array}{c}0.42 \\
(0.07)^{* * *}\end{array}$ & $\begin{array}{c}0.38 \\
(0.08)^{* * *}\end{array}$ \\
\hline Observations & 200 & 200 & 200 & 200 & 103 & 103 \\
\hline R-squared & 0.4 & 0.42 & 0.44 & 0.46 & 0.27 & 0.46 \\
\hline Sample & FULL & FULL & FULL & FULL & DISC & DISC \\
\hline Individual Cor & & YES & YES & YES & & YES \\
\hline Household Co & & & YES & YES & & YES \\
\hline City Fixed Eff & & & & YES & & YES \\
\hline
\end{tabular}

Notes:

1. Each coefficient contains the result of a separate regression in which the dependent variable is "went to engineering college". The reported coefficient is on "above cutoff for admissions."

2. In Panel A, the sample includes upper caste applicants, while the sample in Panel B includes lower caste applicants. Panel C \& D disaggregate the lower caste groups by the two main categories (OBC and SC).

3. The individual-level controls are dummies for OBC and SC categories, a gender dummy, the logarithm of age, dummies for the type of secondary school attended (e.g. English private school, Hindi private school or government school), and controls for whether or not the outcome data comes from the parent or child survey. The household-level controls are household head monthly income as of 1996 (in Rs), dummies for the educational attainment of the household head, a dummy variable for whether the household head is an engineer, a dummy for whether or not the household head uses a computer at work, and the number of other children in the household.

4. In the discontinuity sample, applicants with the top $25 \%$ test scores and the bottom $25 \%$ test scores are excluded from the sample.

5. Standard errors in parentheses. The number of observations and the $\mathrm{R}^{\wedge} 2$ of the regression are listed below the standard errors.

6. Significance at $10 \%$ level is represented by a $*$, at the $5 \%$ level by a ** and at the $1 \%$ level by $* * *$. 
Table 7: Labor Market Outcomes (2SLS)

\begin{tabular}{|c|c|c|c|c|c|c|}
\hline & $\begin{array}{c}\text { Model } 1 \\
(1)\end{array}$ & $\begin{array}{c}\text { Model } 2 \\
(2)\end{array}$ & $\begin{array}{c}\text { Model } 3 \\
\text { (3) }\end{array}$ & $\begin{array}{c}\text { Model } 4 \\
(4)\end{array}$ & $\begin{array}{c}\text { Model } 5 \\
(5) \\
\end{array}$ & $\begin{array}{c}\text { Model } 6 \\
(6)\end{array}$ \\
\hline \multicolumn{7}{|l|}{ Panel A: Upper Caste } \\
\hline Employed & $\begin{array}{c}0.18 \\
(0.09)^{*}\end{array}$ & $\begin{array}{c}0.16 \\
(0.09)^{*}\end{array}$ & $\begin{array}{c}0.16 \\
(0.09)^{*}\end{array}$ & $\begin{array}{c}0.14 \\
(0.09)\end{array}$ & $\begin{array}{c}0.03 \\
(0.18)\end{array}$ & $\begin{array}{c}0.02 \\
(0.18)\end{array}$ \\
\hline Income & $\begin{array}{c}13002.05 \\
(3942.70)^{* * *}\end{array}$ & $\begin{array}{c}11257.85 \\
(3768.96)^{* * *}\end{array}$ & $\begin{array}{c}10189.39 \\
(3718.99)^{* * *}\end{array}$ & $\begin{array}{c}8972.98 \\
(3902.04)^{* *}\end{array}$ & $\begin{array}{l}14338.38 \\
(8729.81)\end{array}$ & $\begin{array}{c}12256.5 \\
(8533.27)\end{array}$ \\
\hline Log(Income) & $\begin{array}{c}2.23 \\
(1.00)^{* *}\end{array}$ & $\begin{array}{c}1.97 \\
(0.96)^{* *}\end{array}$ & $\begin{array}{c}1.95 \\
(0.97)^{* *}\end{array}$ & $\begin{array}{c}1.53 \\
(1.04)\end{array}$ & $\begin{array}{c}1.00 \\
(2.02)\end{array}$ & $\begin{array}{c}0.85 \\
(2.21)\end{array}$ \\
\hline Income Below Median & $\begin{array}{c}-0.30 \\
(0.11)^{* * *} \\
\end{array}$ & $\begin{array}{c}-0.25 \\
(0.11)^{* *} \\
\end{array}$ & $\begin{array}{c}-0.23 \\
(0.11)^{* *}\end{array}$ & $\begin{array}{l}-0.13 \\
(0.11) \\
\end{array}$ & $\begin{array}{l}-0.18 \\
(0.24) \\
\end{array}$ & $\begin{array}{c}0.03 \\
(0.25) \\
\end{array}$ \\
\hline \multicolumn{7}{|c|}{ Panel B: Lower Caste Groups (OBC and SC) } \\
\hline Employed & $\begin{array}{c}0.12 \\
(0.07)^{*}\end{array}$ & $\begin{array}{c}0.1 \\
(0.07)\end{array}$ & $\begin{array}{c}0.1 \\
(0.07)\end{array}$ & $\begin{array}{c}0.09 \\
(0.07)\end{array}$ & $\begin{array}{c}0.12 \\
(0.11)\end{array}$ & $\begin{array}{c}0.07 \\
(0.12)\end{array}$ \\
\hline Income & $\begin{array}{c}6202.71 \\
(1606.85)^{* * *}\end{array}$ & $\begin{array}{c}5692.11 \\
(1596.47)^{* * *}\end{array}$ & $\begin{array}{c}5571.66 \\
(1567.38)^{* * *}\end{array}$ & $\begin{array}{c}5549.22 \\
(1568.88)^{* * *}\end{array}$ & $\begin{array}{c}3729.23 \\
(2596.38)\end{array}$ & $\begin{array}{c}4071.75 \\
(2690.64)\end{array}$ \\
\hline Log(Income) & $\begin{array}{c}1.47 \\
(0.65)^{* *}\end{array}$ & $\begin{array}{c}1.39 \\
(0.65)^{* *}\end{array}$ & $\begin{array}{c}1.37 \\
(0.66)^{* *}\end{array}$ & $\begin{array}{c}1.27 \\
(0.67)^{*}\end{array}$ & $\begin{array}{c}1.44 \\
(1.08)\end{array}$ & $\begin{array}{c}1.07 \\
(1.16)\end{array}$ \\
\hline Income Below Median & $\begin{array}{c}-0.21 \\
(0.07)^{* * * *} \\
\end{array}$ & $\begin{array}{c}-0.18 \\
(0.07)^{* *} \\
\end{array}$ & $\begin{array}{c}-0.17 \\
(0.07)^{* *} \\
\end{array}$ & $\begin{array}{c}-0.16 \\
(0.07)^{* *} \\
\end{array}$ & $\begin{array}{l}-0.17 \\
(0.12) \\
\end{array}$ & $\begin{array}{l}-0.19 \\
(0.12) \\
\end{array}$ \\
\hline \multicolumn{7}{|l|}{ Panel C: OBC } \\
\hline Employed & $\begin{array}{c}0.17 \\
(0.07)^{* *}\end{array}$ & $\begin{array}{c}0.12 \\
(0.07)^{*}\end{array}$ & $\begin{array}{c}0.11 \\
(0.07)\end{array}$ & $\begin{array}{c}0.08 \\
(0.07)\end{array}$ & $\begin{array}{c}0.15 \\
(0.12)\end{array}$ & $\begin{array}{c}0.06 \\
(0.13)\end{array}$ \\
\hline Income & $\begin{array}{c}8206.11 \\
(2431.53)^{* * *}\end{array}$ & $\begin{array}{c}8050.48 \\
(2417.61)^{* * *}\end{array}$ & $\begin{array}{c}6282.15 \\
(2332.41)^{* * *}\end{array}$ & $\begin{array}{c}6343.35 \\
(2354.71)^{* * *}\end{array}$ & $\begin{array}{c}3683.15 \\
(3595.66)\end{array}$ & $\begin{array}{c}1605.28 \\
(3864.82)\end{array}$ \\
\hline Log(Income) & $\begin{array}{c}1.99 \\
(0.76)^{* * *}\end{array}$ & $\begin{array}{c}1.53 \\
(0.74)^{* *}\end{array}$ & $\begin{array}{c}1.35 \\
(0.77)^{*}\end{array}$ & $\begin{array}{c}1.14 \\
(0.77)\end{array}$ & $\begin{array}{c}1.58 \\
(1.17)\end{array}$ & $\begin{array}{c}0.66 \\
(1.26)\end{array}$ \\
\hline Income Below Median & $\begin{array}{c}-0.35 \\
(0.09)^{* * *} \\
\end{array}$ & $\begin{array}{c}-0.32 \\
(0.10)^{* * *}\end{array}$ & $\begin{array}{c}-0.26 \\
(0.09)^{* * *} \\
\end{array}$ & $\begin{array}{c}-0.23 \\
(0.09)^{* *} \\
\end{array}$ & $\begin{array}{c}-0.31 \\
(0.15)^{* *} \\
\end{array}$ & $\begin{array}{l}-0.16 \\
(0.14) \\
\end{array}$ \\
\hline \multicolumn{7}{|l|}{ Panel D: SC } \\
\hline Employed & $\begin{array}{c}0.04 \\
(0.12)\end{array}$ & $\begin{array}{c}0.07 \\
(0.13)\end{array}$ & $\begin{array}{c}0.11 \\
(0.13)\end{array}$ & $\begin{array}{c}0.1 \\
(0.13)\end{array}$ & $\begin{array}{c}0.06 \\
(0.23)\end{array}$ & $\begin{array}{l}-0.01 \\
(0.29)\end{array}$ \\
\hline Income & $\begin{array}{c}3610.12 \\
(1923.58)^{*}\end{array}$ & $\begin{array}{c}3458.77 \\
(1986.11)^{*}\end{array}$ & $\begin{array}{c}4448.97 \\
(2033.25)^{* *}\end{array}$ & $\begin{array}{c}3927.14 \\
(2004.06)^{*}\end{array}$ & $\begin{array}{c}3799.93 \\
(3509.00)\end{array}$ & $\begin{array}{c}2916.02 \\
(4089.24)\end{array}$ \\
\hline Log(Income) & $\begin{array}{c}0.79 \\
(1.11)\end{array}$ & $\begin{array}{c}1.24 \\
(1.15)\end{array}$ & $\begin{array}{c}1.48 \\
(1.18)\end{array}$ & $\begin{array}{c}1.36 \\
(1.19)\end{array}$ & $\begin{array}{c}1.23 \\
(2.08)\end{array}$ & $\begin{array}{c}0.25 \\
(2.69)\end{array}$ \\
\hline Income Below Median & $\begin{array}{l}-0.04 \\
(0.11) \\
\end{array}$ & $\begin{array}{l}-0.04 \\
(0.11) \\
\end{array}$ & $\begin{array}{l}-0.06 \\
(0.11) \\
\end{array}$ & $\begin{array}{l}-0.05 \\
(0.11) \\
\end{array}$ & $\begin{array}{c}0.04 \\
(0.20) \\
\end{array}$ & $\begin{array}{c}0.07 \\
(0.25) \\
\end{array}$ \\
\hline Sample & FULL & FULL & FULL & FULL & DISC & DISC \\
\hline Individual Controls & & YES & YES & YES & & YES \\
\hline Household Controls & & & YES & YES & & YES \\
\hline City Fixed Effects & & & & YES & & YES \\
\hline
\end{tabular}

Notes:

1. Each coefficient contains the result of a separate IV regression in which the dependent variable is either employed, income, $\log ($ income), or income below median, as indicated. The reported coefficient is on "went to engineering college," which is instrumented by "above cutoff for admissions."

2. In Panel A, the sample includes upper caste applicants, while the sample in Panel B includes lower caste applicants. Panel C \& D disaggregate the lower caste groups by the two main categories (OBC and SC).

3. The individual-level controls are dummies for OBC and SC categories, a gender dummy, the logarithm of age, dummies for the type of secondary school attended (e.g. English private school, Hindi private school or government school), and controls for whether or not the outcome data comes from the parent or child survey. The household-level controls are household head monthly income as of 1996 (in Rs), dummies for the educational attainment of the household head, a dummy variable for whether the household head is an engineer, a dummy for whether or not the household head uses a computer at work, and the number of other children in the household.

4. In the discontinuity sample, applicants with the top $25 \%$ test scores and the bottom $25 \%$ test scores are excluded from the sample.

5. Standard errors in parentheses.

6. Significance at $10 \%$ level is represented by a *, at the $5 \%$ level by a ** and at the $1 \%$ level by ***. 
Table 8: Labor Market Estimates, Including Quadratic Control for Score

\begin{tabular}{|c|c|c|c|c|}
\hline & $(1)$ & $(2)$ & (3) & (4) \\
\hline \multicolumn{5}{|l|}{ Panel A: Upper Caste Groups } \\
\hline \multicolumn{5}{|l|}{ First Stage: } \\
\hline \multirow[t]{2}{*}{ went } & 0.17 & 0.18 & 0.2 & 0.17 \\
\hline & $(0.10)^{*}$ & $(0.10)^{*}$ & $(0.10)^{* *}$ & $(0.10)^{*}$ \\
\hline \multicolumn{5}{|l|}{ Second Stage: } \\
\hline \multirow[t]{2}{*}{ Employed } & 0.25 & 0.23 & 0.22 & 0.17 \\
\hline & $(0.57)$ & $(0.56)$ & $(0.51)$ & $(0.59)$ \\
\hline \multirow[t]{2}{*}{ Income } & 19961.81 & 17620.66 & 10613.9 & 5282.21 \\
\hline & (29927.45) & $(27248.31)$ & $(22225.51)$ & (27996.89) \\
\hline \multirow[t]{2}{*}{ Log(Income) } & 3.57 & 3.35 & 2.98 & 3.03 \\
\hline & (7.38) & $(6.83)$ & $(5.93)$ & $(7.81)$ \\
\hline \multirow[t]{2}{*}{ Income Below Median } & -0.28 & -0.24 & -0.12 & 0.11 \\
\hline & $(0.81)$ & $(0.74)$ & $(0.63)$ & $(0.82)$ \\
\hline \multicolumn{5}{|c|}{ Panel B: Lower Caste Groups (OBC and SC) } \\
\hline \multicolumn{5}{|l|}{ First Stage: } \\
\hline \multirow[t]{2}{*}{ went } & 0.48 & 0.48 & 0.48 & 0.48 \\
\hline & $(0.06)^{* * *}$ & $(0.06)^{* * *}$ & $(0.06)^{* * *}$ & $(0.06)^{* * *}$ \\
\hline \multicolumn{5}{|l|}{ Second Stage: } \\
\hline \multirow[t]{2}{*}{ Employed } & 0.31 & 0.29 & 0.27 & 0.25 \\
\hline & $(0.18)^{*}$ & $(0.18)$ & $(0.18)$ & $(0.19)$ \\
\hline \multirow[t]{2}{*}{ Income } & 3571.95 & 4044.27 & 4173.91 & 4101.99 \\
\hline & $(4180.91)$ & (4076.48) & $(4055.74)$ & $(4075.33)$ \\
\hline \multirow[t]{2}{*}{ Log(Income) } & 3.14 & 3.08 & 2.94 & 2.76 \\
\hline & $(1.74)^{*}$ & $(1.71)^{*}$ & $(1.77)^{*}$ & (1.79) \\
\hline \multirow[t]{2}{*}{ Income Below Median } & -0.37 & -0.36 & -0.39 & -0.36 \\
\hline & $(0.19) *$ & $(0.19) *$ & $(0.19)^{* *}$ & $(0.19) *$ \\
\hline Sample & FULL & FULL & FULL & FULL \\
\hline Individual Controls & & YES & YES & YES \\
\hline Household Controls & & & YES & YES \\
\hline City Fixed Effects & & & & YES \\
\hline Quadratic Control in Score & YES & YES & YES & YES \\
\hline
\end{tabular}

Notes:

1. In each panel, the first row presents the results of seperate OLS regrssions in which the dependent variable is "went to engineering college." The coefficient presented is on "above cutoff for admission." In the rest of the panel, the cells contains the result of a separate IV regression in which the dependent variable is either employed, income, $\log$ (income), or income below median, as indicated. The reported coefficient is on "went to engineering college," which is instrumented by "above cutoff for admissions."

2. In Panel A, the sample includes upper caste applicants, while the sample in Panel B includes lower caste applicants.

3. See Table 7 for a discussion of individual and household controls. All regressions also include a quadratic control for test score.

4. Standard errors in parentheses.

5. Significance at $10 \%$ level is represented by a *, at the $5 \%$ level by a ** and at the $1 \%$ level by $* * *$. 
Table 9: Labor Market Outcomes and Socio-Economic Background

\begin{tabular}{|c|c|c|c|}
\hline & (1) & (2) & (3) \\
\hline \multicolumn{4}{|c|}{ Panel A: Upper Caste Groups } \\
\hline Went & $\begin{array}{c}6929.28 \\
(5466.10)\end{array}$ & $\begin{array}{c}4890.88 \\
(5344.92)\end{array}$ & $\begin{array}{c}12102.3 \\
(90330.97)\end{array}$ \\
\hline Below Median & $\begin{array}{c}-8035.22 \\
(3295.76)^{* *}\end{array}$ & $\begin{array}{c}-8102.64 \\
(4316.32)^{*}\end{array}$ & \\
\hline Below Median * Went & $\begin{array}{c}9332.11 \\
(7617.46)\end{array}$ & $\begin{array}{l}11008.92 \\
(7583.77)\end{array}$ & \\
\hline Predicted Score & & & $\begin{array}{c}151.33 \\
(72.80)^{* *}\end{array}$ \\
\hline Predicted Score *Went & & & $\begin{array}{l}-228.38 \\
(176.27) \\
\end{array}$ \\
\hline \multicolumn{4}{|c|}{ Panel B: Lower Caste Groups (OBC and SC) } \\
\hline Went & $\begin{array}{c}9426.9 \\
(2188.89)^{* * *}\end{array}$ & $\begin{array}{c}9581.81 \\
(2146.69)^{* * *}\end{array}$ & $\begin{array}{l}-14981.55 \\
(10621.25)\end{array}$ \\
\hline Below Median & $\begin{array}{c}639.59 \\
(1878.64)\end{array}$ & $\begin{array}{c}3835.14 \\
(2337.27)\end{array}$ & \\
\hline Below Median * Went & $\begin{array}{c}-9137.85 \\
(3249.55)^{* * *}\end{array}$ & $\begin{array}{c}-8918.19 \\
(3245.04)^{* * *}\end{array}$ & \\
\hline Predicted Score & & & $\begin{array}{c}3.54 \\
(19.15)\end{array}$ \\
\hline Predicted Score *Went & & & $\begin{array}{c}65.72 \\
(34.44)^{*}\end{array}$ \\
\hline $\begin{array}{l}\text { Sample } \\
\text { Controls }\end{array}$ & FULL & $\begin{array}{l}\text { FULL } \\
\text { YES }\end{array}$ & FULL \\
\hline
\end{tabular}

Notes:

1. Each column in a panel presents the results of a separate IV regression in which the dependent variable is income. "Predicted Score" is the predicted score from an regression where the dependent variable is an individual's test score and the regressors are the individual and household controls. The individual-level controls are dummies for $\mathrm{OBC}$ and SC categories, a gender dummy, the logarithm of age, dummies for the type of secondary school attended (e.g. English private school, Hindi private school or government school), and controls for whether or not the outcome data comes from the parent or child survey. The household-level controls are household head monthly income as of 1996 (in Rs), dummies for the educational attainment of the household head, a dummy variable for whether the household head is an engineer, a dummy for whether or not the household head uses a computer at work, and the number of other children in the household. "Below Median" is a dummy variable which indicates whether an individual was below the predicted median score for his or her caste group.

2. In Panel A, the sample includes upper caste applicants, while the sample in Panel B includes lower caste applicants.

3. Standard errors in parentheses.

4. Significance at $10 \%$ level is represented by a $*$, at the $5 \%$ level by a $* *$ and at the $1 \%$ level by ***. 
Table 10: Job Characteristics (2SLS)

\begin{tabular}{|c|c|c|c|c|c|c|}
\hline & $\begin{array}{c}\text { Model } 1 \\
(1)\end{array}$ & $\begin{array}{c}\text { Model } 2 \\
(2)\end{array}$ & $\begin{array}{c}\text { Model } 3 \\
\text { (3) }\end{array}$ & $\begin{array}{c}\text { Model } 4 \\
\text { (4) }\end{array}$ & $\begin{array}{c}\text { Model } 5 \\
\text { (5) }\end{array}$ & $\begin{array}{c}\text { Model } 6 \\
(6)\end{array}$ \\
\hline \multicolumn{7}{|l|}{ Panel A: Upper Caste Groups } \\
\hline Works as Engineer & $\begin{array}{c}0.44 \\
(0.12)^{* * *}\end{array}$ & $\begin{array}{c}0.37 \\
(0.11)^{* * *}\end{array}$ & $\begin{array}{c}0.37 \\
(0.11)^{* * *}\end{array}$ & $\begin{array}{c}0.35 \\
(0.12)^{* * *}\end{array}$ & $\begin{array}{c}0.3 \\
(0.25)\end{array}$ & $\begin{array}{c}0.37 \\
(0.26)\end{array}$ \\
\hline Uses Computer in Job & $\begin{array}{c}0.32 \\
(0.14)^{* *}\end{array}$ & $\begin{array}{c}0.31 \\
(0.12)^{* *}\end{array}$ & $\begin{array}{c}0.34 \\
(0.12)^{* * *}\end{array}$ & $\begin{array}{c}0.25 \\
(0.13)^{* *}\end{array}$ & $\begin{array}{c}0.68 \\
(0.34)^{* *}\end{array}$ & $\begin{array}{c}0.4 \\
(0.28)\end{array}$ \\
\hline Uses English in Job & $\begin{array}{c}0.5 \\
(0.15)^{* * *}\end{array}$ & $\begin{array}{c}0.47 \\
(0.15)^{* * *}\end{array}$ & $\begin{array}{c}0.47 \\
(0.15)^{* * *}\end{array}$ & $\begin{array}{c}0.38 \\
(0.15)^{* *}\end{array}$ & $\begin{array}{c}0.78 \\
(0.38)^{* *}\end{array}$ & $\begin{array}{c}0.6 \\
(0.39)\end{array}$ \\
\hline $\begin{array}{l}\text { Strongly Agrees--Views Job as } \\
\text { Successful }\end{array}$ & $\begin{array}{c}0.76 \\
(0.64)\end{array}$ & $\begin{array}{c}0.82 \\
(0.62)\end{array}$ & $\begin{array}{c}0.99 \\
(0.63)\end{array}$ & $\begin{array}{c}1.08 \\
(0.69)\end{array}$ & $\begin{array}{c}0.99 \\
(1.36)\end{array}$ & $\begin{array}{c}1.19 \\
(1.52)\end{array}$ \\
\hline Works in Private Sector & $\begin{array}{c}0.39 \\
(0.12)^{* * *}\end{array}$ & $\begin{array}{c}0.35 \\
(0.11)^{* * *}\end{array}$ & $\begin{array}{c}0.33 \\
(0.11)^{* * *}\end{array}$ & $\begin{array}{c}0.27 \\
(0.11)^{* *}\end{array}$ & $\begin{array}{c}0.34 \\
(0.25)\end{array}$ & $\begin{array}{c}0.28 \\
(0.23)\end{array}$ \\
\hline Works in Government Sector & $\begin{array}{l}-0.01 \\
(0.07)\end{array}$ & $\begin{array}{c}0.02 \\
(0.07)\end{array}$ & $\begin{array}{c}0.04 \\
(0.07)\end{array}$ & $\begin{array}{c}0.07 \\
(0.07)\end{array}$ & $\begin{array}{l}-0.11 \\
(0.14)\end{array}$ & $\begin{array}{c}0.01 \\
(0.14)\end{array}$ \\
\hline Self-Employed/Family-Employed & $\begin{array}{c}-0.11 \\
(0.04)^{* *}\end{array}$ & $\begin{array}{c}-0.1 \\
(0.04)^{* *}\end{array}$ & $\begin{array}{c}-0.1 \\
(0.04)^{* *}\end{array}$ & $\begin{array}{c}-0.11 \\
(0.04)^{* *}\end{array}$ & $\begin{array}{l}-0.09 \\
(0.08)\end{array}$ & $\begin{array}{c}-0.15 \\
(0.08)^{*}\end{array}$ \\
\hline \multicolumn{7}{|c|}{ Panel B: Lower Caste Groups (OBC and SC) } \\
\hline Works as Engineer & $\begin{array}{c}0.27 \\
(0.07)^{* * *}\end{array}$ & $\begin{array}{c}0.23 \\
(0.07)^{* * *}\end{array}$ & $\begin{array}{c}0.22 \\
(0.07)^{* * *}\end{array}$ & $\begin{array}{c}0.22 \\
(0.07)^{* * *}\end{array}$ & $\begin{array}{c}0.29 \\
(0.13)^{* *}\end{array}$ & $\begin{array}{c}0.22 \\
(0.13) *\end{array}$ \\
\hline Uses Computer in Job & $\begin{array}{c}0.11 \\
(0.08)\end{array}$ & $\begin{array}{c}0.11 \\
(0.07)\end{array}$ & $\begin{array}{c}0.11 \\
(0.08)\end{array}$ & $\begin{array}{c}0.11 \\
(0.08)\end{array}$ & $\begin{array}{c}0.1 \\
(0.14)\end{array}$ & $\begin{array}{c}0 \\
(0.14)\end{array}$ \\
\hline Uses English in Job & $\begin{array}{c}0.24 \\
(0.08)^{* * *}\end{array}$ & $\begin{array}{c}0.2 \\
(0.08)^{* *}\end{array}$ & $\begin{array}{c}0.19 \\
(0.08)^{* *}\end{array}$ & $\begin{array}{c}0.18 \\
(0.08)^{* *}\end{array}$ & $\begin{array}{c}0.06 \\
(0.13)\end{array}$ & $\begin{array}{l}-0.05 \\
(0.15)\end{array}$ \\
\hline $\begin{array}{l}\text { Strongly Agrees--Views Job as } \\
\text { Successful }\end{array}$ & $\begin{array}{c}0.23 \\
(0.09)^{* *}\end{array}$ & $\begin{array}{c}0.22 \\
(0.09)^{* *}\end{array}$ & $\begin{array}{c}0.21 \\
(0.09)^{* *}\end{array}$ & $\begin{array}{c}0.18 \\
(0.09)^{* *}\end{array}$ & $\begin{array}{c}0.14 \\
(0.15)\end{array}$ & $\begin{array}{l}-0.01 \\
(0.16)\end{array}$ \\
\hline Works in Private Sector & $\begin{array}{c}0.04 \\
(0.07)\end{array}$ & $\begin{array}{c}0.01 \\
(0.07)\end{array}$ & $\begin{array}{c}0.02 \\
(0.07)\end{array}$ & $\begin{array}{l}-0.01 \\
(0.07)\end{array}$ & $\begin{array}{c}0.12 \\
(0.12)\end{array}$ & $\begin{array}{c}0.08 \\
(0.13)\end{array}$ \\
\hline Works in Government Sector & $\begin{array}{c}0.07 \\
(0.05)\end{array}$ & $\begin{array}{c}0.08 \\
(0.05)\end{array}$ & $\begin{array}{c}0.08 \\
(0.06)\end{array}$ & $\begin{array}{c}0.08 \\
(0.06)\end{array}$ & $\begin{array}{c}0.03 \\
(0.09)\end{array}$ & $\begin{array}{c}0.04 \\
(0.10)\end{array}$ \\
\hline Self-Employed/Family-Employed & $\begin{array}{c}-0.09 \\
(0.04)^{* *}\end{array}$ & $\begin{array}{c}-0.08 \\
(0.04)^{* *} \\
\end{array}$ & $\begin{array}{c}-0.08 \\
(0.04)^{* *} \\
\end{array}$ & $\begin{array}{c}-0.09 \\
(0.04)^{* *} \\
\end{array}$ & $\begin{array}{c}-0.1 \\
(0.06) \\
\end{array}$ & $\begin{array}{l}-0.12 \\
(0.07)^{*}\end{array}$ \\
\hline Sample & FULL & FULL & FULL & FULL & DISC & DISC \\
\hline Individual Controls & & YES & YES & YES & & YES \\
\hline Household Controls & & & YES & YES & & YES \\
\hline City Fixed Effects & & & & YES & & YES \\
\hline
\end{tabular}

Notes:

1. Each coefficient contains the result of a separate IV regression in which the dependent variable is as indicated. The reported coefficient is on "went to engineering college," which is instrumented by "above cutoff for admissions."

2. In Panel A, the sample includes upper caste applicants, while the sample in Panel B includes lower caste applicants.

3. See Table 7 for a discussion of the included control variables.

4. In the discontinuity sample, applicants with the top $25 \%$ test scores and the bottom $25 \%$ test scores are excluded from the sample.

5. Standard errors in parentheses.

6. Significance at $10 \%$ level is represented by a *, at the $5 \%$ level by a $* *$ and at the $1 \%$ level by $* * *$. 
Table 11: Social Networks and Beliefs

\begin{tabular}{|c|c|c|c|c|c|c|}
\hline & $\begin{array}{c}\text { Model } 1 \\
(1) \\
\end{array}$ & $\begin{array}{c}\text { Model } 2 \\
(2) \\
\end{array}$ & $\begin{array}{c}\text { Model } 3 \\
(3) \\
\end{array}$ & $\begin{array}{c}\text { Model } 4 \\
(4) \\
\end{array}$ & $\begin{array}{c}\text { Model } 5 \\
(5) \\
\end{array}$ & $\begin{array}{c}\text { Model } 6 \\
(6) \\
\end{array}$ \\
\hline \multicolumn{7}{|l|}{ Panel A: Upper Caste Groups } \\
\hline Family or Friends Helped Find Job & $\begin{array}{c}-0.2 \\
(0.07)^{* * *}\end{array}$ & $\begin{array}{c}-0.15 \\
(0.07)^{* *}\end{array}$ & $\begin{array}{c}-0.15 \\
(0.07)^{* *}\end{array}$ & $\begin{array}{c}-0.15 \\
(0.07)^{* *}\end{array}$ & $\begin{array}{c}-0.55 \\
(0.19)^{* * *}\end{array}$ & $\begin{array}{c}-0.41 \\
(0.16)^{* *}\end{array}$ \\
\hline Index of Caste Identity & $\begin{array}{l}-0.21 \\
(0.26)\end{array}$ & $\begin{array}{l}-0.15 \\
(0.26)\end{array}$ & $\begin{array}{l}-0.05 \\
(0.25)\end{array}$ & $\begin{array}{c}0.06 \\
(0.27)\end{array}$ & $\begin{array}{l}-0.65 \\
(0.56)\end{array}$ & $\begin{array}{c}0.11 \\
(0.59)\end{array}$ \\
\hline Reservation Index & $\begin{array}{l}-0.04 \\
(0.34)\end{array}$ & $\begin{array}{l}-0.17 \\
(0.33)\end{array}$ & $\begin{array}{l}-0.29 \\
(0.33)\end{array}$ & $\begin{array}{c}0.05 \\
(0.35)\end{array}$ & $\begin{array}{l}-0.11 \\
(0.79)\end{array}$ & $\begin{array}{l}-0.11 \\
(1.04)\end{array}$ \\
\hline $\begin{array}{l}\text { Agrees with Reservations for Females in } \\
\text { Government }\end{array}$ & $\begin{array}{l}-0.05 \\
(0.15)\end{array}$ & $\begin{array}{l}-0.09 \\
(0.15)\end{array}$ & $\begin{array}{l}-0.15 \\
(0.14)\end{array}$ & $\begin{array}{c}0.02 \\
(0.15)\end{array}$ & $\begin{array}{c}0.04 \\
(0.32)\end{array}$ & $\begin{array}{l}-0.05 \\
(0.43)\end{array}$ \\
\hline $\begin{array}{l}\text { Agrees with Reservations for Females in } \\
\text { Engineering Universities }\end{array}$ & $\begin{array}{l}-0.05 \\
(0.15)\end{array}$ & $\begin{array}{l}-0.05 \\
(0.14)\end{array}$ & $\begin{array}{l}-0.07 \\
(0.14)\end{array}$ & $\begin{array}{c}0.1 \\
(0.15)\end{array}$ & $\begin{array}{l}-0.37 \\
(0.35)\end{array}$ & $\begin{array}{l}-0.23 \\
(0.49)\end{array}$ \\
\hline $\begin{array}{l}\text { Reservations for Minorities in } \\
\text { Engineering Universities Fair }\end{array}$ & $\begin{array}{c}0.03 \\
(0.15)\end{array}$ & $\begin{array}{c}0.02 \\
(0.15)\end{array}$ & $\begin{array}{l}-0.04 \\
(0.15)\end{array}$ & $\begin{array}{c}0.02 \\
(0.16)\end{array}$ & $\begin{array}{c}0.06 \\
(0.33)\end{array}$ & $\begin{array}{c}0.35 \\
(0.55)\end{array}$ \\
\hline Participates in Government & $\begin{array}{c}-0.2 \\
(0.14) \\
\end{array}$ & $\begin{array}{c}-0.19 \\
(0.13) \\
\end{array}$ & $\begin{array}{l}-0.15 \\
(0.13) \\
\end{array}$ & $\begin{array}{l}-0.17 \\
(0.14) \\
\end{array}$ & $\begin{array}{l}-0.19 \\
(0.28) \\
\end{array}$ & $\begin{array}{l}-0.24 \\
(0.33) \\
\end{array}$ \\
\hline \multicolumn{7}{|l|}{ Panel B: Lower Caste Groups (OBC and SC) } \\
\hline Family or Friends Helped Find Job & $\begin{array}{l}-0.01 \\
(0.04)\end{array}$ & $\begin{array}{c}0 \\
(0.04)\end{array}$ & $\begin{array}{c}0 \\
(0.04)\end{array}$ & $\begin{array}{c}0 \\
(0.04)\end{array}$ & $\begin{array}{l}-0.05 \\
(0.08)\end{array}$ & $\begin{array}{l}-0.04 \\
(0.08)\end{array}$ \\
\hline Index of Caste Identity & $\begin{array}{l}-0.22 \\
(0.18)\end{array}$ & $\begin{array}{l}-0.19 \\
(0.17)\end{array}$ & $\begin{array}{l}-0.24 \\
(0.18)\end{array}$ & $\begin{array}{l}-0.26 \\
(0.18)\end{array}$ & $\begin{array}{l}-0.44 \\
(0.28)\end{array}$ & $\begin{array}{l}-0.43 \\
(0.32)\end{array}$ \\
\hline Reservation Index & $\begin{array}{c}0.41 \\
(0.25)\end{array}$ & $\begin{array}{c}0.37 \\
(0.24)\end{array}$ & $\begin{array}{c}0.35 \\
(0.25)\end{array}$ & $\begin{array}{c}0.37 \\
(0.25)\end{array}$ & $\begin{array}{c}0.84 \\
(0.40)^{* *}\end{array}$ & $\begin{array}{c}0.99 \\
(0.46)^{* *}\end{array}$ \\
\hline $\begin{array}{l}\text { Agrees with Reservations for Females in } \\
\text { Government }\end{array}$ & $\begin{array}{c}0.15 \\
(0.10)\end{array}$ & $\begin{array}{c}0.14 \\
(0.10)\end{array}$ & $\begin{array}{c}0.13 \\
(0.11)\end{array}$ & $\begin{array}{c}0.12 \\
(0.10)\end{array}$ & $\begin{array}{c}0.37 \\
(0.18)^{* *}\end{array}$ & $\begin{array}{c}0.49 \\
(0.21)^{* *}\end{array}$ \\
\hline $\begin{array}{l}\text { Agrees with Reservations for Females in } \\
\text { Engineering Universities }\end{array}$ & $\begin{array}{c}0.2 \\
(0.11)^{*}\end{array}$ & $\begin{array}{c}0.19 \\
(0.11)^{*}\end{array}$ & $\begin{array}{c}0.19 \\
(0.11)^{*}\end{array}$ & $\begin{array}{c}0.18 \\
(0.11)^{*}\end{array}$ & $\begin{array}{c}0.39 \\
(0.19)^{* *}\end{array}$ & $\begin{array}{c}0.29 \\
(0.20)\end{array}$ \\
\hline $\begin{array}{l}\text { Reservations for Minorities in } \\
\text { Engineering Universities Fair }\end{array}$ & $\begin{array}{l}-0.03 \\
(0.11)\end{array}$ & $\begin{array}{l}-0.04 \\
(0.10)\end{array}$ & $\begin{array}{l}-0.06 \\
(0.11)\end{array}$ & $\begin{array}{l}-0.03 \\
(0.11)\end{array}$ & $\begin{array}{c}0.24 \\
(0.17)\end{array}$ & $\begin{array}{c}0.35 \\
(0.21)^{*}\end{array}$ \\
\hline Participates in Government & $\begin{array}{l}-0.03 \\
(0.07) \\
\end{array}$ & $\begin{array}{l}-0.02 \\
(0.07) \\
\end{array}$ & $\begin{array}{l}-0.01 \\
(0.07) \\
\end{array}$ & $\begin{array}{c}0.01 \\
(0.07) \\
\end{array}$ & $\begin{array}{l}-0.16 \\
(0.12) \\
\end{array}$ & $\begin{array}{c}-0.1 \\
(0.13) \\
\end{array}$ \\
\hline Sample & $\overline{\text { FULL }}$ & FULL & FULL & FULL & DISC & DISC \\
\hline Individual Controls & & YES & YES & YES & & YES \\
\hline Household Controls & & & YES & YES & & YES \\
\hline City Fixed Effects & & & & YES & & YES \\
\hline
\end{tabular}

Notes:

1. Each coefficient contains the result of a separate IV regression in which the dependent variable is as indicated. The reported coefficient is on "went to engineering college," which is instrumented by "above cutoff for admissions."

2. In Panel A, the sample includes upper caste applicants, while the sample in Panel B includes lower caste applicants.

3. See Table 7 for a discussion of the included control variables.

4. In the discontinuity sample, applicants with the top $25 \%$ test scores and the bottom $25 \%$ test scores are excluded from the sample.

5. Standard errors in parentheses.

6. Significance at $10 \%$ level is represented by a *, at the $5 \%$ level by a ** and at the $1 \%$ level by ***. 


\begin{tabular}{|c|c|c|c|}
\hline & $\begin{array}{l}\text { Above } \\
\text { (1) }\end{array}$ & $\begin{array}{l}\text { Below } \\
\text { (2) }\end{array}$ & $\begin{array}{c}\text { Difference } \\
\text { (3) }\end{array}$ \\
\hline \multicolumn{4}{|c|}{ A. Percent Found } \\
\hline Upper Castes & 0.380 & 0.334 & $\begin{array}{c}0.046 \\
(0.033)\end{array}$ \\
\hline Other Backward Castes & 0.329 & 0.375 & $\begin{array}{l}-0.046 \\
(0.039)\end{array}$ \\
\hline Scheduled Castes & 0.375 & 0.367 & $\begin{array}{c}0.008 \\
(0.042)\end{array}$ \\
\hline \multicolumn{4}{|c|}{ B. Difference In Total Score (Found - Not Found) } \\
\hline Upper Castes & 4.677 & -1.973 & $\begin{array}{c}6.65 \\
(10.906)\end{array}$ \\
\hline Other Backward Castes & -0.733 & 5.998 & $\begin{array}{c}-6.731 \\
(11.372)\end{array}$ \\
\hline Scheduled Castes & -1.030 & -6.177 & $\begin{array}{c}5.146 \\
(7.877)\end{array}$ \\
\hline \multicolumn{4}{|c|}{ C. Difference in Percent Female (Found - Not Found) } \\
\hline Upper Castes & 0.037 & 0.068 & $\begin{array}{c}-0.03 \\
(0.054)\end{array}$ \\
\hline Other Backward Castes & -0.042 & 0.005 & $\begin{array}{l}-0.047 \\
(0.055)\end{array}$ \\
\hline Scheduled Castes & 0.006 & -0.021 & $\begin{array}{c}0.027 \\
(0.064)\end{array}$ \\
\hline \multicolumn{4}{|c|}{ D. Difference in Age (Found - Not Found) } \\
\hline Upper Castes & 0.043 & 0.007 & $\begin{array}{c}0.036 \\
(0.174)\end{array}$ \\
\hline Other Backward Castes & -0.614 & -0.020 & $\begin{array}{l}-0.593 \\
(0.878)\end{array}$ \\
\hline Scheduled Castes & 0.018 & 0.246 & $\begin{array}{l}-0.228 \\
(0.320)\end{array}$ \\
\hline \multicolumn{4}{|c|}{ E. Difference in Attended (Found - Not Found) } \\
\hline Upper Castes & 0.072 & 0.013 & $\begin{array}{c}0.059 \\
(0.058)\end{array}$ \\
\hline Other Backward Castes & 0.039 & 0.027 & $\begin{array}{c}0.013 \\
(0.051)\end{array}$ \\
\hline Scheduled Castes & -0.012 & 0.000 & $\begin{array}{l}-0.012 \\
(0.062)\end{array}$ \\
\hline
\end{tabular}

Notes:

1. In Panel A, we report the percentage of individuals found above (Column 1) and below (Column

2) the cutoff for each caste group. The difference in these means is reported in Column 3. The standard error is presented below the difference in parentheses.

2. In Panel B - E, we report the difference in means of pre-characteristics for those found and not found during the surveying. We report this difference for those above the cutoff in Column 1 and for those below the cutoff in Column 2. The difference in these means is reported in Column 3. The standard error is presented below the difference in parentheses.

3. Significance at $10 \%$ level is represented by a $*$, at the $5 \%$ level by a $* *$ and at the $1 \%$ level by $* * *$. 
Appendix Table 2: Correlations Between Parent and Applicant Outcomes

\begin{tabular}{lccccc}
\hline \hline & \multicolumn{5}{c}{ Answered By Parent } \\
\cline { 2 - 6 } & $\begin{array}{c}\text { Father } \\
\text { Ancome }\end{array}$ & $\begin{array}{c}\text { Applicant } \\
\text { Employed }\end{array}$ & $\begin{array}{c}\text { Applicant } \\
\text { Income }\end{array}$ & $\begin{array}{c}\text { Applicant } \\
\text { Log(Income) }\end{array}$ & $\begin{array}{c}\text { Applicant Inc } \\
<\text { Median }\end{array}$ \\
\hline Father Income & 0.62 & & & & \\
Applicant Employed & $(0.16)^{* * *}$ & & & & \\
Applicant Income & 0.87 & & 0.86 & \\
Applicant Log(Income) & $(0.03)^{* * *}$ & & $(0.03)^{* * *}$ & 0.8 \\
Applicant Income $<$ Median & & & & $(0.05)^{* * *}$ \\
& & & & & \\
\end{tabular}

Notes:

1. Each coefficient contains the result of a separate OLS regression in which the dependent variable is the variable indicated as asnswered by the Applicant. The reported coefficient is on the same variable as reported by the parent.

2. Standard errors in parentheses.

3. Significance at $10 \%$ level is represented by a *, at the $5 \%$ level by a ** and at the $1 \%$ level by ***. 